\title{
KONSEP KOPERASI BUNG HATTA DALAM PERSPEKTIF EKONOMI SYARIAH
}

\author{
RUSTAM EFFENDI \\ Universitas Islam Riau \\ Jl. Kaharuddin Nasution, No. 113, Perhentian Marpoyan Pekanbaru 28284 \\ e-mail: bsb_bm@yahoo.co.id \\ BOY SYAMSUL BAKHRI \\ Universitas Islam Riau \\ Jl. Kaharuddin Nasution, No. 113, Perhentian Marpoyan Pekanbaru 28284 \\ e-mail: bsb_bm@yahoo.co.id \\ ZUL IHSAN MU'ARRIF \\ Universitas Islam Riau \\ Jl. Kaharuddin Nasution, No. 113, Perhentian Marpoyan Pekanbaru 28284 \\ e-mail: bsb_bm@yahoo.co.id
}

\begin{abstract}
Abstrak: Penelitian ini dilatarbelakangi oleh belum banyaknya tokoh ekonomi Indonesia yang berkontribusi dalam perkembangan ekonomi syariah. Bung Hatta merupakan salah satu tokoh intelektual di bidang ekonomi yang mencurahkan idenya untuk kemajuan bangsa. Konsep koperasi merupakan bukti keprihatinan Bung Hatta akan kondisi ekonomi masyarakat Indonesia yang terjebak hutang oleh lintah darat. Konsep koperasi yang ditawarkan oleh Bung Hatta merupakan bentuk modern dari adat istiadat dan tradisi masyarakat Indonesia, yaitu semangat kolektivisme (gotong royong dan tolong menolong). Konsep tersebut diduga memiliki keterkaitan dengan konsep ekonomi syariah. Adapun yang menjadi perumusan masalah dalam penelitian ini adalah bagaimana konsep koperasi Bung Hatta dalam perspektif ekonomi syariah. Tujuan penelitian ini adalah untuk mengetahui konsep koperasi Bung Hatta dalam perspektif ekonomi syariah. Subjek penelitian ini adalah Bung Hatta. Sementara objek dalam penelitian ini adalah konsep koperasi Bung Hatta dalam perspektif ekonomi syariah. Jenis penelitian yang digunakan adalah jenis penelitian kepustakaan. Pendekatan yang digunakan melalui pendekatan filosofis dan komparatif. Teknik analisis data yang digunakan dalam penelitian ini yakni kualitaitif, yaitu dengan proses editing, klasifikasi, memberi kode, dan penafsiran. Penafsiran dilakukan dengan membandingkan konsep koperasi Bung Hatta dengan konsep ekonomi syariah. Hasil penelitian adalah terdapat persamaan konsep koperasi Bung Hatta dengan ekonomi syariah, yaitu pada akad, nilai-nilai dasar, prinsip tolong menolong, prinsip manfaat, prinsip mashlahah, fungsi, karakteristik, produksi, dan distribusi.
\end{abstract}

Kata kunci: Koperasi, Bung Hatta, Ekonomi Syariah

\section{PENDAHULUAN}

Manusia membutuhkan penghidupan yang lebih baik untuk bertahan hidup. Karena itu merupakan ketetapan yang sudah digariskan kepada manusia.
Untuk dapat bertahan hidup, diperlukan sebuah usaha untuk memperoleh keperluan hidupnya.

Seiring dengan bertambahnya kemampuan dan kecerdasannya dalam 
menghadapi permasalahan untuk memperoleh kemakmuran hidupnya, diperlukan sebuah ilmu untuk mengelola penghidupan manusia. Ilmu itu adalah ilmu ekonomi.

Manusia merupakan makhluk sosial yang hidup secara berkelompok sehingga diperlukan sebuah sistem untuk memenuhi kebutuhan. Sistem ekonomi yang dianut, berbeda di setiap kelompok masyarakat. Tergantung dari kebutuhan masing-masing kelompok. Ada yang menganut sistem liberalisme/kapitalisme dan ada yang menganut sistem sosialisme/komunisme.

Dalam perkembangan selanjutnya, berbagai landasan teoritis ekonomi syariah telah memberikan konstribusi pemikiran bagi sistem ekonomi liberal dan sosialis. Kebijakan dan praktik ekonomi yang berlangsung pada masa Rasulullah Shallallahu 'Alaihi Wasallam dan al-Khulafa al-Rasyidin merupakan contoh empiris yang dijadikan dasar bagi para cendikiawan muslim dalam melahirkan teori-teori ekonominya.

Di Indonesia, tidak sedikit tokoh pemikir ekonomi syariah pada abad 1819 yang belum banyak diketahui. Seperti Haji Samanhoedi, H.O.S. Cokroaminoto, Haji Agus Salim, Buya Hamka, dan Bung Hatta.

Adapun, salah satu tokoh yang memberikan kontribusi pemikiran ekonomi syariah hingga abad 20 adalah Bung Hatta. Sistem ekonomi yang dikembangkan oleh Bung Hatta, didasarkan kepada kondisi sosial masyarakat Indonesia yang kental akan kultur dan budayanya.

Bung Hatta merupakan salah satu pemimpin bangsa, pemikir, dan juga peletak dasar Indonesia. Bung Hatta dikenal sebagai ekonom Indonesia yang banyak mencurahkan pemikirannya terhadap kemajuan bangsa pada umumnya dan bidang ekonomi pada khususnya (Setiyarini, 2014: 212).
Dari latarbelakang dan kehidupannya sehari-hari, ajaran-ajaran agama Islam sudah melekat kuat didalam diri Hatta. Hal ini menandakan bahwa Hatta adalah orang yang sangat berpegang teguh terhadap ajaran Islam.

Di dalam pergerakan keislaman memang Hatta tidak menampakkan diri, namun Hatta memiliki prinsip tersendiri dalam perjuangan Islam. Bagaikan air tenang yang menghanyutkan. Tanpa disadari oleh beberapa pihak, Hatta membawa nilai Islam kedalam bagian Konstitusional.

Jika dilihat dari pemikiranpemikiran Hatta, walaupun secara simbolis tidak menunjukkan simbol keislaman, akan tetapi sarat akan makna keislaman.Undang-Undang Dasar 1945 Pasal 33 Ayat 1 menyatakan bahwa perekonomian disusun sebagai usaha bersama berdasar atas asas kekeluargaan. Artinya, setiap anggota masyarakat berpartisipasi dalam mengendalikan jalannya roda perekonomian nasional. Kegiatan yang dilakukan masyarakat ialah dengan usaha bersama. Kerugian dan keuntungan, ditanggung bersama sebagai prinsip atas asas kekeluargaan.

Ternyata, di dalam istilah ekonomi syariah, sistem tersebut dinamakan dengan sistem bagi hasil ( ). Dimana, sistem tersebut adalah sistem kemitraan beberapa pihak dalam sebuah usaha tertentu, serta keuntungan dan kerugian ditanggung oleh kedua belah pihak. Sistem ini, didalam ekonomi syariah terdapat beberapa akad, seperti mudharabah, musyarakah, muzara'ah, musaqah dan mugharasah.

Salah satu bentuk badan usaha dari sistem ekonomi kerakyatan adalah koperasi. Konsep awal koperasi yang dibawa oleh Hatta sangat sesuai dengan sistem ekonomi syariah, walaupun dalam perjalanannya banyak terjadi perubahan sistem hingga saat sekarang ini. Koperasi merupakan sebuah usaha bersama dari setiap anggota koperasi yang 
dioperasikan oleh orang seorang berdasarkan asas kekeluargaan. Wujud dari koperasi adalah sebuah usaha bersama sebagai bentuk dari persaudaraan karena berdasarkan asas kekeluargaan. Usaha bersama yang dilakukan bukan merupakan keuntu-ngan satu pihak saja. Prinsip kebersamaan yang diutamakan. Keuntungan dan kerugian pun akan ditanggung bersama.

Konsep koperasi Bung Hatta, didalam ekonomi syariah dikenal dengan syirkah. Menurut Mardani (2013: 220), syirkah merupakan bentuk kerjasama antara dua orang atau lebih dalam hal permodalan, keterampilan, atau kepercayaan, dalam usaha tertentu, dengan pembagian keuntungan berdasarkan nisbah. Antara koperasi Bung Hatta dengan syirkah, memiliki prinsip yang sama dan sejalan yaitu prinsip kebersamaan.

Konsep koperasi merupakan bukti keprihatinan Bung Hatta atas kondisi masyarakat Indonesia yang memprihatinkan akibat penjajahan terutama kondisi ekonomi.

Pemikiran Bung Hatta yang memiliki nilai-nilai keislaman menjadi sangat menarik untuk dikaji, melihat masih minimnya pembahasan pemikiran ekonomi Bung Hatta dari perspektif ekonomi syariah.

Oleh karena itu penulis tertarik untuk meneliti pemikiran Bung Hatta sebagai seorang tokoh intelektual dalam sejarah Indonesia yang menempatkan nilai-nilai dan perjuangan Islam secara strategis melalui konstitusionalnya dengan judul "Konsep Koperasi Bung Hatta dalam Perspektif Ekonomi Syariah (Studi dengan Pendekatan Filosofis dan Komparatif)".

Agar penelitian ini lebih terarah pada sasaran yang diinginkan dengan benar dan tepat, maka penulis memfokuskan pembahasan penelitian ini pada konsep koperasi Bung Hatta dalam perspektif ekonomi syariah. Adapun yang menjadi perumusan masalah dalam penelitian ini adalah bagaimana konsep koperasi Bung Hatta dalam perspektif ekonomi syariah? Sedangkan yang menjadi tujuan penelitian ini adalah untuk mengetahui konsep koperasi bung Hatta dalam perspektif ekonomi syariah.

\section{METODE}

Jenis penelitian yang digunakan pada penelitian ini adalah jenis penelitian kepustakaan (literer). Jenis penelitian kepustakaan adalah salah satu jenis metode penelitian kualitatif yang lokasi atau tempat penelitiannya dilakukan di pustaka, dokumen, arsip, dan lain sejenisnya (Prastowo, 2016: 190).

Oleh karena itulah, studi kepustakaan terhadap penelitian yang didominasi oleh pengumpulan data nonlapangan sekaligus meliputi objek yang diteliti dan data yang digunakan untuk membicarakannya, sebagai objek utama (primer) sekaligus sekunder (Prastowo, 2016: 191).

Adapun, pendekatan merupakan sifat ilmu pengetahuan. Melaluinya, objek diungkapkan secara lebih objektif. Dalam kaitannya dengan hal ini, tampil pendekatan sosiologis, historis, psikologis, antropologis, ekonomis, politis, dan sebagainya (Ratna dalam Prastowo, 2016: 180).

Jadi, pendekatan memiliki hubungan erat dengan model analisis yang akan digunakan. Pendekatan secara filosofis, menjelaskan konsep koperasi Bung Hatta dan konsep ekonomi syariah. Pendekatan secara komparatif membandingkan konsep koperasi Bung Hatta dengan konsep koperasi syariah

Adapun yang menjadi subjek penelitian ini adalah Bung Hatta. Sedangkan yang menjadi objek penelitian ini adalah konsep koperasi Bung Hatta menurut perspektif ekonomi syariah.

Untuk melengkapi data yang diperlukan dalam penelitian ini, teknik pengumpulan data yang digunakan 
adalah teknik dokumentasi. Teknik dokumentasi dipilih sebagai metode untuk pengumpulan data pada penelitian ini dikarenakan sumber penelitian pada penelitian ini dalam bentuk dokumen. Hal ini juga berdasarkan pada objek penelitian ini adalah pemikiran Bung Hatta yang tertuang pada beberapa karya tulisnya.

\section{KAJIAN TEORI Koperasi}

Menurut Echols dan Hassan Shadily (2010: 147), koperasi dikenal dengan istilah co-operation yang artinya kerja sama. Dalam Kamus Belanda-Indonesia (Moeimam dan Hein Steinhauer, 2008: 208) disebut dengan istilah coöperatie yang berarti bekerja sama. Dalam Kamus al-Maurid (2006: 988), dikenal dengan istilah ( ) yang artinya kerja sama, dan tolong menolong.

Dalam Kamus Bahasa Indonesia (2008: 753), koperasi merupakan perserikatan yang bertujuan memenuhi keperluan kebendaan para anggotanya dengan cara menjual barang-barang kebutuhan dengan harga murah (tidak bermaksud mencari untung).

Chaniago memberi definisi koperasi sebagai suatu perkumpulan yang beranggotakan orang-orang atau badan hukum yang memberi kebebasan masuk dan keluar sebagai anggota dengan bekerja sama secara kekeluargaan; menjalankan usaha untuk mempertinggi kesejahteraan jasmaniah para anggotanya (dalam Soesilo, 2008: 3).

$$
\text { Organisasi Buruh Sedunia }
$$

(International Labor Organization / ILO) dalam resolusinya nomor 127 yang dibuat pada tahun 1966, mendefinisikan koperasi ialah suatu kumpulan orang, biasanya yang memiliki kemampuan ekonomi terbatas, yang melalui suatu bentuk organisasi perusahaan yang diawasi secara demokratis. Masingmasing memberikan sumbangan yang setara terhadap modal yang diperlukan dan bersedia menanggung resiko serta menerima imbalan yang sesuai dengan usaha yang mereka lakukan (dalam Soesilo, 2008: 4).

Erdman mengatakan bahwa koperasi ialah usaha bersama, merupakan badan hukum, anggota ialah pemilik, yang menggunakan jasanya, dan mengembalikan semua penerimaan di atas biayanya kepada anggota, sesuai dengan transaksi yang mereka jalankan dengan koperasi (dalam Subandi, 2010: 19).

Dari beberapa pengertian diatas, dapat ditarik kesimpulan bahwa koperasi merupakan perkumpulan dari orangorang secara sukarela dengan tujuan untuk meningkatkan kesejahteraan anggotanya.

\section{Sejarah Perkembangan Koperasi di Indonesia}

Koperasi di Indonesia dipelopori oleh R. Aria Wiratmadja, seorang patih di Purwekorto pada tahun 1896, yang mendirikan koperasi simpan pinjam dengan modal sebagian besar berasal dari dirinya sendiri. Kegiatan R. Aria Wiriatmadja dikembangkan lebih lanjut oleh De Wolf van Westerrode, asisten residen wilayah Purwokerto di Banyumas, dengan mengembangkan model koperasi simpan pinjam lumbung dengan modal yang diambil dari zakat (Hendar, 2010: 6).

Ide koperasi kemudian dikembangkan oleh Boedi Oetomo pada tahun 1908 dan Serikat Islam tahun 1911. Keduanya sama-sama mengembangkan koperasi konsumsi untuk memenuhi kebutuhan rumah tangga dengan cara membuka toko-toko koperasi (Hendar, 2010: 7).

Pada tahun 1927 di Surabaya didirikan Indonesische Studieclub oleh dokter Soetomo (pendiri Boedi Oetomo) dan melalui organisasi tersebut beliau menganjurkan berdirinya koperasi. Kegiatan serupa juga dilakukan oleh 
Partai Nasional Indonesia di bawah pimpinan Ir. Soekarno dan pada tahun 1929 mereka menyelenggarakan kongres koperasi di Betawi. Keputusan kongres tersebut menyatakan bahwa untuk meningkatkan kemakmuran penduduk bumi putera, harus didirikan berbagai macam koperasi di seluruh pulau Jawa khususnya dan Indonesia pada umumnya (Hendar, 2010: 7).

Setelah

memproklamasikan

Indonesia

kemerdekaan, dengan tegas perkoperasian ditulis di dalam UUD 1945. Drs. Moh. Hatta berusaha memasukkan rumusan perkoperasian di dalam "konstitusi". Pasal 33 UUD 1945 ayat 1 beserta penjelasannya menyatakan bahwa perekonomian disusun sebagai usaha bersama berdasarkan asas kekeluargaan. Dalam penjelasannya disebutkan bahwa bangun pereko-nomian yang sesuai dengan asas kekeluargaan tersebut adalah koperasi (Hendar, 2010: 7).

\section{Ekonomi Syariah}

\section{Pengertian Ekonomi Syariah}

Kata ekonomi syariah merupakan gabungan dari dua kata, yaitu "ekonomi" dan "syariah". Adapun, kata ekonomi berasal dari bahasa Yunani, yaitu oikosnomos yang dalam bahasa Inggris disebut dengan management of household or estate (tata laksana rumah tangga atau pemilikan) (Rosyidi, 2014: 4).

Sedangkan kata syariah atau syariat (شَرْنَحَ) dalam Kamus Al-Maurid (2006: 712) bermakna syariat, ajaran, undangundang, dan hukum. Pada asalnya, kata syari'ah (شَرِيْعَة berarti jalan lempang dan terang menuju mata air. Mata air yang menjadi sumber air minum bagi manusia dan hewan (Ammar dan Abu Fatiah al Adnani, 2016: 202).

Adapun defenisi syariah secara istilah adalah apa yang Allah tetapkan dalam kitab-Nya (Alqur'an) dan melalui lisan Rasul-Nya agar mereka meraih kebahagiaan hidup di dunia dan akhirat
(Ammar dan Abu Fatiah al Adnani, 2016: 202).

Pengertian ilmu ekonomi syariah yang dikemukan oleh Akram Khan adalah Islamic economics aims the study of the human falah (well-being) achieved by organizing the resources of the earth on the basic of cooperation and participation (ilmu ekonomi syariah bertujuan untuk melakukan kajian tentang kebahagiaan hidup manusia yang dicapai dengan mengorganisasikan sumber daya alam atas dasar bekerja sama dan partisipasi) (dalam Huda, et.al., 2008: 1).

Menurut Manan, Islamic economics is a social science which studies the economics problems of a people imbued with the values of Islam(ilmu ekonomi syariah adalah ilmu pengetahuan sosial yang mempelajari masalah-masalah ekonomi masyarakat yang diilhami oleh nilai-nilai Islam) (dalam Huda, et.al., 2008: 2).

Dari keterangan diatas, dapat disimpulkan bahwa ilmu ekonomi syariah adalah ilmu yang mengatur penghidupan manusia secara aktual, baik dalam produksi, distribusi, maupun konsumsi, sesuai dengan syariat Islam, berdasarkan Alqur'an, Hadis, serta ijma' para ulama, untuk mencapai kebahagiaan dunia dan akhirat.

\section{Nilai-nilai Dasar Ekonomi Syariah}

Terdapat tiga nilai dasar (Misanam, et.al., 2011: 58) yang menjadi pembeda ekonomi syariah dengan lainnya, yaitu: (a) Adl. Keadilan ( $a d l$ ) merupakan nilai paling asasi dalam ajaran Islam. Menegakkan keadilan dan memberantas kezaliman adalah tujuan utama dari risalah para Rasul-Nya. Keadilan, sering kali diletakkan sederajat dengan kebajikan dan ketakwaan (Misanam, et.al., 2011: 59); (b) Khilafah. Nilai khilafah secara umum berarti tanggung jawab sebagai pengganti atau utusan Allah di alam semesta. Manusia diciptakan Allah untuk menjadi khalifah 
di muka bumi, yaitu menjadi wakil Allah untuk memakmurkan bumi dan alam semesta (Misanam, et.al., 2011: 62); dan (c) Takaful. Jaminan masyarakat (takaful) merupakan bantuan yang diberikan masyarakat kepada anggotanya yang terkena musibah atau masyarakat yang tidak mampu. Jaminan masyarakat ini tidak saja bersifat material, melainkan juga bersifat nonmateri (Misanam, et.al., 2011: 63).

\section{Prinsip-prinsip Ekonomi Syariah}

Adapun prinsip-prinsip ekonomi syariah, yaitu: Pertama, Prinsip Tauhidi (Unity). Dalam bermuamalah yang harus diperhatikan adalah bagaimana seharusnya menciptakan suasana dan kondisi bermuamalah yang tertuntun oleh nilai-nilai ketuhanan. Paling tidak dalam setiap melakukan aktivitas bermuamalah ada semacam keyakinan dalam hati bahwa Allah selalu mengawasi seluruh gerak langkah kita dan selalu bersama kita. Kalau pemahaman ini terbentuk dalam setiap pelaku muamalah (bisnis), maka akan terjadi muamalah yang jujur, amanah, dan sesuai tuntunan syariah (Mardani, 2013: 8). Allah SWT berfirman:
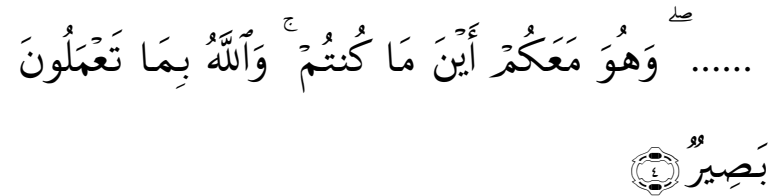

Artinya: "Dan Dia bersama kamu di mana saja kamu berada. Dan Allah Maha melihat apa yang kamu kerjakan" (Al-Hadiid, 57: 4)

Kedua, Prinsip Halal. Dalam melakukan muamalah, benda yang akan ditransaksikan harus suci zatnya, sesuai dengan Firman Allah dalam Alqur'an surat:

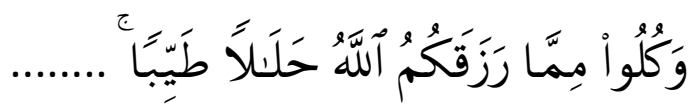

Artinya: "Dan makanlah dari apa yang telah diberikan Allah kepadamu sebagai rezeki yang halal dan baik, ........" (Al-Maidah, 5: 88).

Halalan-thayyiban pada ayat ini mengandung pengertian bahwa zat pada benda yang di transaksikan harus halal dan cara memperoleh benda tersebut harus dengan cara yang halal pula. Dengan demikian, Islam tidak membenarkan seseorang melakukan muamalah terhadap benda yang haram secara zatnya dan tidak dibenarkan melakukan muamalah terhadap benda yang diperoleh dengan cara yang tidak sah (Rozalinda, 2016: 5).

Ketiga, Prinsip Mashlahah. Mashlahah adalah sesuatu yang ditunjukkan oleh dalil hukum tertentu yang membenarkan atau membatalkannya atas segala tindakan manusia dalam rangka mencapai tujuan syara', yaitu memelihara agama, jiwa, akal, harta benda, dan keturunan (Mardani, 2013: 10).

Prinsip ini sejalan dengan tujuan syariat (maqashid syariah) yakni mendatangkan kemaslahatan dan menghindari kemudaratan pada setiap transaksi yang dilakukan, sesuai dengan kaidah (Rozalinda, 2016: 7).

Keempat, Prinsip Mubah. Prinsip dasar dalam setiap bentuk muamalah dalam Islam adalah mubah atau boleh. Setiap akad muamalah yang dilakukan manusia dalam rangka pemenuhan kebutuhan hidupnya adalah boleh selama tidak ada dalil yang menyatakan keharamannya. Hal ini didasarkan pada kaidah fiqih (Rozalinda, 2016: 4).

Kelima, Prinsip Manfaat. Benda yang ditransaksikan harus mempunyai manfaat, baik manfaat yang dapat dirasakan secara langsung maupun tidak langsung. Jadi tidak dibenarkan melakukan transaksi terhadap benda yang akan mendatangkan kesia-siaan. Kesia-siaan itu termasuk sikap mubazir dan orang yang melakukan tindakan mubazir termasuk saudara setan 
(Rozalinda, 2016: 6). Allah SWT berfirman:

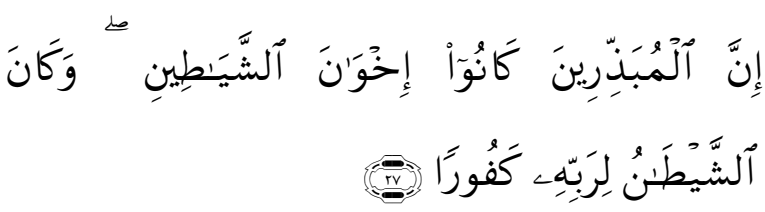

Artinya: "Sesungguhnya orang-orang pemboros itu adalah saudara setan dan setan itu sangat ingkar kepada Tuhannya". (AlIsra', 17: 27).

Keenam, Prinsip Kerelaan. Dalam Islam, setiap akad atau transaksi yang dilakukan dengan sesama manusia harus dilakukan atas dasar suka sama suka atau keralaan. Hal ini dilakukan agar dalam setiap transaksi tidak terjadi karena paksaan dan intimidasi pada salah satu pihak atau pihak lain (Rozalinda, 2016: 7). Allah SWT berfirman:

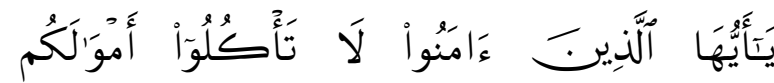

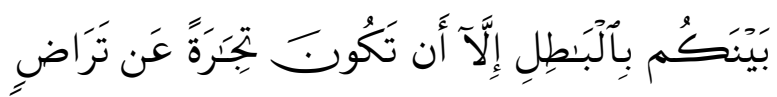

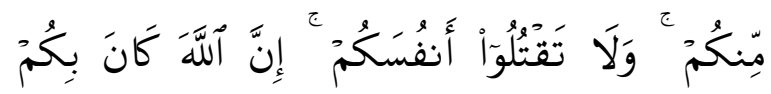
رَحِيَمَا

Artinya: "Wahai orang-orang yang beriman, janganlah kamu saling memakan harta sesamamu dengan jalan yang batil (tidak benar), kecuali dalam perdagangan yang berlaku atas dasar suka sama suka di antara kamu". (An-Nisa', 4: 29).

Ketujuh, Prinsip Tolong Menolong. Manusia merupakan makhluk sosial yang senantiasa membutuhkan manusia lain dalam rangka memenuhi segala kebutuhan hidupnya. Untuk itu, perlu dikembangkan sikap hidup tolongmenolong dengan sesama manusia dalam setiap aspek kehidupan (Rozalinda, 2016: 9). Allah SWT berfirman:

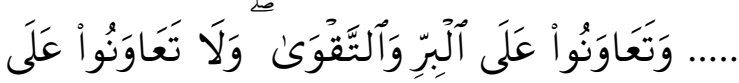

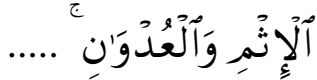

Artinya: ".....Dan tolong-menolonglah kamu dalam (mengerjakan) kebajikan dan takwa dan jangan tolong menolong dalam berbuat dosa dan permusuhan.......". (AlMaidah, 5: 2).

Kedelapan, sesuai dengan ketentuan syariat dan aturan pemerintah. Dalam Islam prinsip yang berlaku adalah melukan transaksi harus sesuai dengan apa yang diatur dalam syariat dan peraturan pemerintah. Transaksi yang dilakukan dengan cara melawan hukum yang berlaku atau bertentangan dengan ketentuan syariat dipandang tidak sah (Rozalinda, 2016: 6). Allah SWT berfirman:

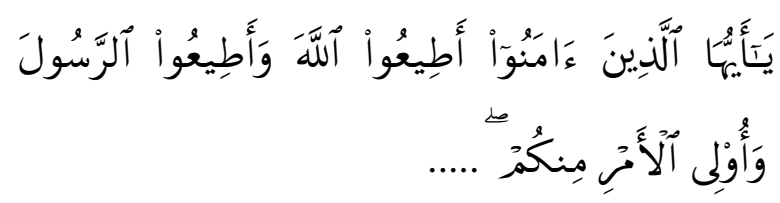

Artinya: "Wahai orang-orang yang beriman, taatilah Allah dan taatilah Rasul (Muhammad) dan Ulil Amri (pemegang kekuasaan) diantara kamu". (An-Nisa', 59)

\section{Karakteristik Ekonomi Syariah}

Ada beberapa karakteristik dalam ekonomi syariah (Nasution, et.al., 2010: 18), yaitu: Pertama, Harta kepunyaan Allah dan manusia merupakan khalifah atas harta. Karakteristik pertama ini terdiri dari dua bagian (Nasution, et.al., 2010: 18), yaitu: (1) Semua harta baik benda maupun alat produksi adalah milik Allah. Allah SWT berfirman: 


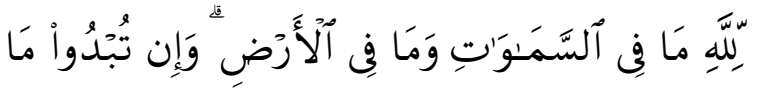

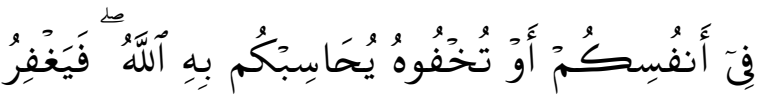

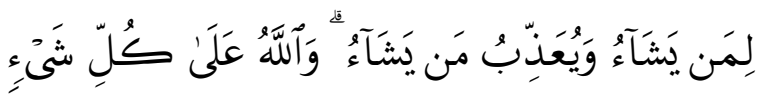
قَدِيرُ

Artinya: "Milik Allah-lah apa yang ada di langit dan apa yang ada di bumi. Jika kamu nyatakan apa yang ada di dalam hatimu atau kamu menyembunyikan, niscaya Allah memperhitungkannya (tentang perbuatan itu) bagimu. Dia mengampuni siapa yang Dia kehendaki dan mengazab siapa yang Dia kehendaki. Allah Mahakuasa atas segala sesuatu." (Al-Baqarah, 2: 284).

Dan (2) Manusia adalah khalifah atas harta miliknya, Allah SWT berfirman:

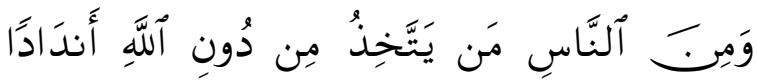

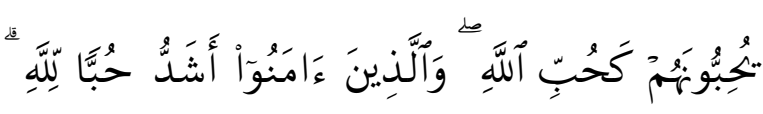

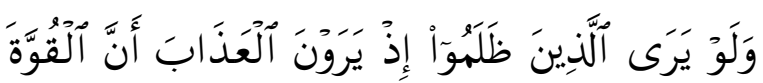

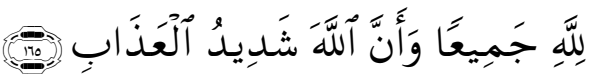

Artinya: "Dan Dialah yang menjadikan kamu sebagai khalifah-khalifah di bumi dan Dia mengangkat (derajat) sebagian kamu di atas yang lain, untuk mengujimu atas (karunia) yang diberikan-Nya kepadamu. Sesungguhnya Tuhanmu sangat cepat memberi hukuman dan sungguh, Dia Maha Pengam-pun, Maha Penyayang" (al-An'aam ayat 165)
Kedua, ekonomi terikat dengan akidah, syariah (hukum), dan moral. Hubungan ekonomi syariah dengan akidah dan syariah, memungkinkan aktivitas ekonomi dalam Islam menjadi ibadah. Sedangkan di antara bukti hubungan ekonomi dan moral dalam Islam (Nasution, et.al., 2010: 22) adalah: (1) Larangan terhadap pemilik dalam penggunaan hartanya yang dapat menimbulkan kerugian atas harta orang lain atau kepentingan masyarakat; (2) Larangan melakukan penipuan dalam transaksi; (3) Larangan menimbun (menyimpan) emas dan perak atau sarana-sarana moneter lainnya, sehingga mencegah peredaran uang; dan (4) Larangan melakukan pemborosan, karena akan menghancurkan individu dalam masyarakat. Allah SWT berfirman:

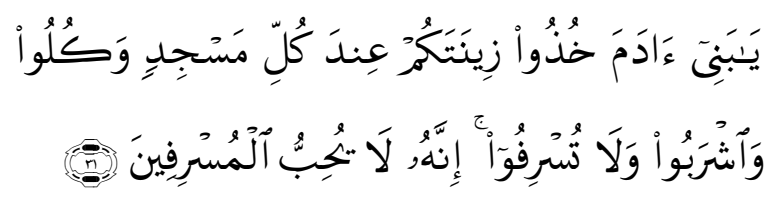

Artinya: "Wahai anak сисu Adam, pakailah pakaianmu yang bagus pada setiap (memasuki) masjid, makan dan minumlah, tetapi janganlah berlebih-lebihan. Sungguh, Allah tidak menyukai orang-orang yang berlebihlebihan." (al-A'raf, 7: 31).

Ketiga, keseimbangan antara kerohanian dan kebendaan. Sesungguhnya, Islam tidak memisahkan antara kehidupan dunia dengan akhirat. Setiap aktivitas manusia di dunia akan berdampak pada kehidupannya kelak di akhirat. Oleh karena itu, aktivitas keduniaan kita tidak boleh mengorbankan kehidupan akhirat (Nasution, et.al., 2010: 23).

Keempat, Ekonomi syariah menciptakan keseimbangan antara kepentingan individu dengan kepentingan umum. Arti keseimbangan dalam Islam adalah Islam tidak mengakui 
hak mutlak dan kebebasan mutlak, tetapi mempunyai batasan-batasan tertentu, termasuk dalam bidang hak milik. Hanya keadilan yang dapat melindungi keseimbangan antara batasan-batasan yang ditetapkan dalam sistem Islam untuk kepemilikan individu dan umum (Nasution, et.al., 2010: 24).

Kelima, kebebasan individu dijamin dalam Islam. Individu-individu dalam perekonomian Islam diberikan kebebasan untuk beraktivitas, baik secara perorangan maupun kolektif, untuk mencapai tujuan. Namun, kebebasan tersebut tidak boleh melanggar aturanaturan yang telah digariskan Allah Shubhanahu Wata 'Ala dalam Alqur'an maupun Hadis. Dengan demikian, kebebasan tersebut sifatnya tidak mutlak (Nasution, et.al., 2010: 26).

Keenam, Social Justice (Keadilan Sosial). Gabungan nilai khilafah dan nilai $m a ' a d$ melahirkan prinsip keadilan sosial. Keadilan diartikan dengan suka sama suka (antarraddiminkum) dan satu pihak tidak menzalimi pihak lain (latazlimuna wa la tuzlamun) (Karim, 2010: 43).

Ketujuh, Negara diberi wewenang turut campur dalam perekonomian. Islam memperkenankan negara untuk mengatur masalah perekonomian agar kebutuhan masyarakat-baik secara individu maupun sosial-dapat terpenuhi secara proporsional. Dalam Islam, negara berkewajiban melindungi kepentingan masyarakat dari ketidakadilan yang dilakukan oleh seseorang atau sekelompok orang ataupun dari negara lain. Negara juga berkewajiban memberikan jaminan sosial agar seluruh masyarakat dapat hidup secara layak (Nasution, et.al., 2010: 27).

Kedelapan, bimbingan Konsumsi. Dalam hal bimbingan konsumsi, Allah SWT berfirman:

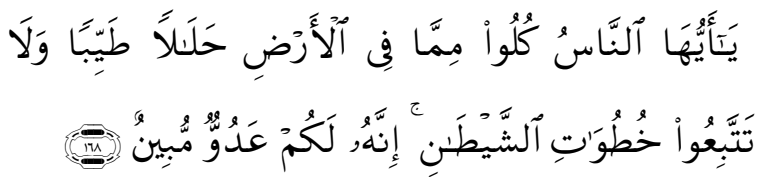

Artinya: "Wahai manusia! Makanlah dari (makanan) yang halal dan baik yang terdapat di bumi, dan janganlah kamu mengikuti langkah-langkah setan. Sungguh, setan itu musuh yang nyata bagimu".(Al-Baqarah, 2: 168)

Kesembilan, larangan Riba. Islam menekankan pentingnya memfungsikan uang pada bidangnya yang normal, yaitu sebagai fasilitas transaksi dan alat penilaian barang. Di antara faktor yang menyelewengkan uang dari bidangnya yang normal adalah bunga (riba) (Nasution, et.al., 2010: 29). Allah SWT berfirman:

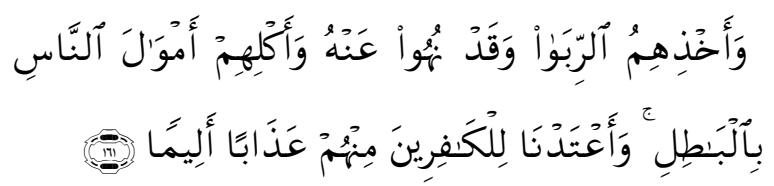

Artinya: "Dan karena mereka menjalankan riba, Padahal Sesungguhnya mereka telah dilarang darinya, dan karena mereka memakan harta benda orang dengan jalan yang tidak sah (batil). Maka kami telah menyediakan untuk orang-orang yang kafir di antara mereka azab yang pedih." (An-Nisa, 4: 161).

\section{Koperasi Syariah \\ Gambaran tentang Koperasi Syariah}

Secara umum prinsip operasional koperasi adalah membantu kesejahteraan para anggota dalam bentuk gotong royong dan tentunya prinsip tersebut tidaklah menyimpang dari sudut pandang syariah yaitu prinsip gotong royong (ta'awun 'alal birri) dan bersifat kolektif (berjemaah) dalam membangun kemandirian hidup. Melalui hal inilah, perlu adanya proses internalisasi terhadap pola pemikiran tata cara pengelolaan, produk-produk, dan hukum yang diberlakukan harus sesuai dengan syariah. Dengan kata lain, koperasi 
syariah merupakan sebuah konversi dari koperasi konvensional melalui pendekatan yang sesuai dengan syariat Islam dan peneladanan ekonomi yang dilakukan Rasulullah dan para sahabatnya (Buchori, 2009: 5).

Konsep utama operasional koperasi syariah adalah menggunakan akad syirkah mufawadhoh yakni sebuah usaha yang didirikan secara bersama-sama oleh dua orang atau lebih, masing-masing memberikan kontribusi dana dalam porsi yang sama besar dan berpartisipasi dalam kerja dengan bobot yang sama pula. Masing-masing partner saling menanggung satu sama lain dalam hak dan kewajiban (Buchori, 2009: 5).

\section{Landasan Dasar Sistem Koperasi Syariah}

Landasan dasar koperasi syariah (Buchori, 2009: 16) antara lain koperasi melalui pendekatan sistem syariah, yakni: (a) Merupakan sistem ekonomi Islam yang integral dan merupakan suatu kumpulan dari barang-barang atau bagian-bagian yang bekerja secara bersama-sama sebagai suatu keseluruhan (Buchori, 2009: 17); dan (b) Merupakan bagian dari nilai-nilai dan ajaran-ajaran Islam yang mengatur bidang perekonomian umat yang tidak terpisahkan dari aspek-aspek lain dari keseluruhan ajaran Islam yang komprehensif dan integral (Buchori, 2009: 17).

Menurut Buchori (2009: 17), tujuan sistem koperasi syariah yaitu: (a) Mensejahterakan ekonomi anggotanya sesuai norma dan moral Islam; (b) Menciptakan persaudaraan dan keadilan sesama anggota; dan (c) Pendistribusian pendapatan dan kekayaan yang merata sesama anggota berdasarkan kontribusinya. Agama Islam mentolerir kesenjangan kekayaan dan penghasilan karena manusia tidak sama dalam hal karakter, kemampuan, kesungguhan, dan bakat. Perbedaan di atas tersebut merupakan penyebab perbedaan dalam pendapatan dan kekayaan(Buchori, 2009: 20). Allah SWT berfirman:

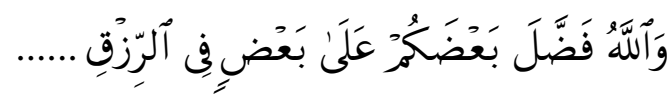

Artinya: "Dan Allah melebihkan sebagian kamu atas sebagian yang lain dalam hal rezeki, ......." (An-Nahl, 16: 71).

Adapun kebebasan pribadi dalam kemaslahatan sosial yang didasarkan pada pengertian bahwa manusia diciptakan hanya untuk tunduk kepada Allah (Buchori, 2009: 22).

Selain itu, Buchori (2009: 23) menjelaskan ada beberapa karakteristik koperasi syariah, yaitu: (a) Mengakui hak milik anggota terhadap modal usaha; (b) Tidak melakukan transaksi dengan menetapkan bunga (riba); (c) Berfungsinya institusi ziswaf; (d) Mengakui mekanisme pasar yang ada; (e) Mengakui motif mencari keuntungan; (f) Mengakui kebebasan berusaha; dan (g) Mengakui adanya hak bersama.

\section{Sumber Dana, Produk, dan Jasa-jasa}

Sumber dana dapat diperoleh dari anggota, pinjaman atau dana-dana yang bersifat hibah atau sumbangan. Semua jenis sumber dana tersebut dapat diklasifikasikan sifatnya ada yang komersil, hibah atau sumbangan atau sekedar titipan saja(Buchori, 2009: 28).

Secara umum, sumber dana koperasi diklasifikasikan sebagai berikut: (a) Simpanan pokok. Simpanan pokok merupakan modal awal anggota yang disetorkan dimana besar simpanan pokok tersebut sama dan tidak boleh dibedakan antara anggota. Akad syariah simpanan pokok tersebut masuk katagori akad musyarakah. konsep pendirian koperasi syariah tepatnya menggunakan konsep syirkah mufawadhoh yakni sebuah usaha yang didirikan secara bersama-sama dua orang atau lebih, masing-masing memberikan kontribusi dana dalam porsi yang sama dan berpartisipasi dalam kerja 
dengan bobot yang sama pula. (Buchori, 2009: 28-29); (b) Simpanan wajib. Simpanan wajib masuk dalam kategori modal koperasi sebagaimana simpanan pokok dimana besar kewajibannya diputuskan berdasarkan hasil syuro (musyawarah) anggota serta penyetorannya dilakukan secara kontinu setiap bulannya sampai seseorang dinyatakan keluar dari keanggotaan koperasi syariah (Buchori, 2009: 29); dan (c) Simpanan sukarela. Simpanan anggota merupakan bentuk investasi dari anggota atau calon anggota yang memiliki kelebihan dana kemudian menyimpannya di koperasi syariah (Buchori, 2009: 29).

Sesuai dengan sifat koperasi dan fungsinya, maka sumber dana yang diperoleh haruslah disalurkan kepada anggota maupun calon anggota. Sifat penyaluran dananya adalah yang berkategori komersil yakni dengan menggunakan bagi hasil (mudharabah atau musyarakah) dan juga dengan jual beli (piutang murabahah, piutang salam, piutang istsihna' dan sejenisnya), bahkan ada juga yang bersifat jasa umum, misalnya pengalihan piutang (hawalah), sewa menyewa barang (ijarah) atau pemberian manfaat berupa pendidikan dan sebagainya (Buchori, 2009: 32).

Disamping produk kerja sama dan jual beli koperasi syariah juga dapat melakukan kegiatan jasa layanan (Buchori, 2009: 33) antara lain Jasa alIjarah (sewa), Jasa wadi'ah (titipan), Hawalah (anjak piutang), Rahn (gadai), Wakalah (perwakilan), Kafalah (penjaminan), dan Qardh (pinjaman lunak) (Buchori, 2009: 38).

\section{Distribusi bagi hasil}

Distribusi pendapatan yang dimaksud adalah pembagian pendapatan atas pengelolaan dana yang diterima koperasi syariah dibagi kepada para anggota yang memiliki jenis simpanan atau kepada para pemilik modal yang telah memberikan pinjaman kepada koperasi syariah dalam bentuk mudharabah atau musyarakah. Sedangkan pembagian yang bersifat tahunan (periode khusus) maka distribusi pendapatan tersebut termasuk kategori SHU (Sisa Hasil Usaha) dalam aturan koperasi (Buchori, 2009: 39).

Untuk pembagian bagi hasil kepada anggota yang memiliki jenis simpanan atau pemberi pinjaman adalah didasarkan kepada hasil usaha riil yang diterima koperasi pada saat bulan berjalan. Umumnya ditentukan berdasarkan nisbah yaitu rasio keuntungan antara koperasi syariah dan anggota atau pemberi pinjaman terhadap hasil riil usahanya. Misalnya nisbah 30 : 70 , yaitu jenis simpanan qurban anggota adalah 30 sedangkan untuk koperasi 70 terhadap keuntungan bersih koperasi (laba bulan berjalan). Lain halnya dengan koperasi konvensional pendapatan dari jasa pinjaman koperasi disebut jasa pinjaman (bunga) tanpa melihat hasil keuntungan riil melainkan dari saldo jenis simpanan. Maka dengan demikian pendapatan bagi hasil dari koperasi syariah bisa naik turun sedangkan untuk konvensional bersifat stabil alias tetap dari saldo tanpa melihat jerih payah usaha koperasi syariah. Selanjutnya apabila koperasi syariah menerima pinjaman khusus (restricted investment atau mudharabah muqayyadah), maka pendapatan bagi hasil usaha khusus tersebut hanya dibagikan kepada Pemberi pinjaman dan koperasi syariah. Bagi koperasi pendapatan tersebut dianggap sebagai pendapatan jasa atas mudharabah muqayyadah (Buchori, 2009: 39-40).

\section{BUNG HATTA DAN KONSEP KOPERASI Biografi Bung Hatta}

Mohammad Hatta lahir di Bukittinggi pada 12 Agustus 1902 dari ayah yang bernama Haji Mohammad Jamil dan ibu bernama Siti Saleha. Ayahnya berasal dari daerah Batu Hampar, 
sementara ibunya berasal dari kota Bukittinggi (Abbas, 2010: 23-24).

Nama Mohammad Hatta yang sebenarnya adalah Mohammad Athar. Kata Mohammad diambil dari nama Nabi, sementara kata Athar berasal dari bahasa Arab yang artinya harum. Oleh masyarakat Minangkabau, kata Athar ini sering diucapkan Atta, lama kelamaan berubah menjadi Hatta (Abbas, 2010: 24).

Ayah Hatta adalah anak dari Syekh Arsyad, seorang guru agama dan pimpinan Tariqat Naqsyabandi yang cukup terkenal didaerahnya. Sedangkan ibunya adalah anak dari Ilyas Bagindo Marah, yaitu seorang pedagang yang cukup kaya di kota Bukittinggi (Abbas, 2010: 24).

Dalam keluarga, Hatta adalah anak kedua, kakaknya bernama Rafi'ah yang lahir tahun 1900 dari hasil perkawinan ibunya dengan Mas Agus Haji Ning, yaitu seorang pedagang dari Palembang yang sudah sering berhubungan dagang dengan Ilyas Bagindo Marah (Abbas, 2010: 24).

Dimasa kecil, Hatta bersekolah di Bukittinggi (beberapa tahun disekolah dasar yang mulanya ditempuhnya lebih secara privat), di Padang di ELS (Europeesche Largere School, sekolah dasar untuk orang kulit putih) sampai 1913 (dari kelas 5 sampai kelas 7), kemudian di MULO (Meer Uitgebreid Lager Onderwijs, SMP berbahasa Belanda) sampai 1917 (Noer, 2012: 5).

Selain keluarga, pergaulan juga banyak memengaruhi perhatian Hatta pada perekonomian. Di Padang ia mengenal para pedagang yang menjadi anggota Serikat Usaha, semacam kamar dagang bersifat lokal, terutama sekretarisnya, Taher Marah Sutan. Juga di Padang ini ia mengenal dan aktif dalam pergerakan Jong Sumatranen Bond (JSB, Perkumpulan Pemuda Sumatera)(Noer, 2012: 9).

Setelah tamat dari Padang, Hatta melanjutkan studi ke Sekolah Dagang
Hendrik School di Jakarta. Di Jakarta, dia tinggal di rumah Radja bangsawan dari Bengkulu, yaitu seorang bekas inspektur kepala sekolah untuk wilayah Sumatera bagian Selatan (Abbas, 2010: 30).

Di Jakarta tentu wawasan Hatta tentang pergerakan nasional bertambah luas dan dalam. Apalagi ketika bersekolah di Jakarta itu, seperti telah dikatakan, ia menjadi bendahara pimpinan pusat JSB. Sebagai pelajar, Hatta juga sering berkunjung ke rumah Haji Agus Salim, yang terkenal dekat hubungannya dengan para pemuda. Rumah Salim ketika itu menjadi pusat kaderisasi para pemuda secara tidak resmi, suatu kebiasaan yang terus dilakukan tokoh ini sampai Indonesia merdeka, terutama pada tahuntahun 1950-an, sebelum ia meninggal dunia pada 1954 (Noer, 2012: 15).

Setelah tiga tahun belajar. Hatta menyelesaikan studi di Sekolah Dagang PHS tahun 1921 dengan menempati ranking ketiga. Semula dia sempat tertarik untuk kembali bekerja dengan imbalan gaji permulaan f350. Tetapi kemudian Hatta memutuskan untuk melanjutkan studinya ke negeri Belanda. Di Belanda, Hatta kuliah di Handels Hoogere School, yaitu sebuah sekolah tinggi ekonomi di Rotterdam. Dia mengambil jurusan ekonomi perdagangan. Dua tahun kemudian dia telah meraih gelar sarjana muda. Hatta kemudian melanjutkan ke tingkat sarjana tetapi ketika dia bersiap-siap menempuh ujian sarjana lengkap dia pindah ke jurusan lain. Jurusan yang dimasukinya adalah jurusan ekonomi kenegaraan, karena itu ia terpaksa memperpanjang masa kuliahnya. Kuliah ini baru diselesaikan Hatta dalam tahun 1932 (Abbas, 2010: 35).

Selain aktif di dalam pergerakan keorganisasian, Bung Hatta juga produktif di dalam membuat sebuah karya. Hal ini dilakukan sebagai bentuk kontribusinya dalam perkembangan ekonomi. Diantara karyanya antara lain: Beberapa Fasal 
Ekonomi I, Beberapa Fasal Ekonomi II, Kumpulan Karangan, Masalah Bantuan Perkembangan Ekonomi Bagi Indonesia, Teori Politik dan Orde Ekonomi, Membangun Koperasi dan Koperasi Membangun, dan Pengantar ke Djalan Ilmu dan Pengetahuan.

Bung Hatta meninggal dunia pada Jumat, 14 maret 1980 setelah siangnya, dengan susah payah karena sakit, menunaikan shalat Jumat di masjid Mataram, masjid yang tetap ia kunjungi tiap Jumat atau pun shalat tarawih, semenjak ia tinggal di Jalan Diponegoro, dan bila tidak sedang ke luar kota (Noer, 2015: 173).

\section{Konsep Koperasi Bung Hatta Dasar Ideologi Koperasi Bung Hatta}

Koperasi merupakan usaha bersama berdasar atas asas kekeluargaan. Semangat kolektivisme Indonesia itu yang akan dihidupkan kembali dengan koperasi, mengutamakan kerjasama dalam suasana kekeluargaan antara manusia pribadi, bebas dari penindasan dan paksaan (Hatta, 1967: 35 dan 37).

Disini tak ada pertentangan antara majikan dan buruh; antara pemimpin dan pekerja. Segala yang bekerja adalah anggota daripada koperasinya, samasama bertanggungjawab atas keselamatan rumah tangganya. Demikian pula para anggota koperasi, sama-sama bertanggungjawab atas koperasi mereka (Hatta, 1954: 203).

Koperasi tujuannya yang utama bukanlah mencari keuntungan, tetapi mencapai keperluan hidup bersama. Keuntungan hanya terbawa dalam melaksanakan usaha. Usaha yang terutama untuk memperkuat sendi perusahaan ialah menyimpan. Uang yang disimpan itu, dijadikan pokok tolongmenolong bagi koperasi kredit. Dengan pinjaman bergiliran, masing-masing perusahaan koperasi dapat memperkuat modal usahanya (Hatta, 1967: 36).
Koperasi artinya bekerja bersama membela keperluan bersama, dalam waktu baik, maupun waktu buruk. Laba sama dipungut, rugi sama dipikul. Peraturan seperti itu menjadi suatu didikan kepada anggota-anggota koperasi. Peraturan itu saja dapat mencegah orang yang setengah hati masuk menjadi anggota (Hatta, 1954: 191).

Wujud koperasi ialah memenuhi keperluan bersama, bukan mencari keuntungan, maka perlu dinyatakan dasarnya. Koperasi, jika mau subur hidupnya, mestilah berdiri atas dua tiang, yaitu solidaritet (setia bersekutu) dan individualitet (kesadaran akan harga diri sendiri) (Hatta, 1954: 126).

Apabila anggota koperasi tidak mempunyai rasa solidaritet, ia tidak merasa kepentingan bersama. Koperasi baginya jalan untuk pembela keperluan dirinya sendiri. Dalam keadaan semacam itu, koperasi mudah dirusak oleh konkurennya yang menjual barang keperluan umum. Lawan tadi, menurunkan buat sementara harga barang-barangnya. Anggota yang tidak mempunyai rasa solidaritet, mudah terpedaya dengan taktik semacam itu. Ia lari membeli ketempat lawan koperasinya sendiri. Nanti, jika koperasi sudah mati, ia baru merasa sakitnya. Karena, toko yang menjual murah tadi, sekarang menaikkan kembali harga barangnya (Hatta, 1954: 128).

Sadar diri adalah suatu sifat, karakter kukuh, yang tidak boleh disamakan artinya dengan individualisme (dasar yang mendahulukan hak orang-seorang daripada hak masyarakat). Individualisme menuntut kemerdekaan orang-seorang bertindak untuk mencapai keperluan hidupnya. Ia tak mau orangseorang diikat oleh masyarakat. Tetapi, indivualitet adalah sifat pada orangseorang yang menandakan kehalusan budi beserta dengan ketaguhan wataknya, yang memaksa orang lain 
menghargai dan memandang akan dia (Hatta, 1954: 126).

Koperasi sebagai persekutuan citacita mempunyai syaratnya sendiri yang harus dipenuhi oleh barangsiapa yang hendak mendirikannya. Oleh karena citacita yang mengikat persekutuan ini, maka koperasi itu hendaklah dipikul dan dijunjung oleh mereka yang sama citacitanya. Koperasi adalah persekutuan merdeka, bukan perseku-tuan paksaan. Itulah sebabnya, maka tiap-tiap koperasi mengemukakan dalam peraturan dasarnya bahwa anggotanya boleh berhenti setiap waktu (Hatta, 1954: 190).

Anggota itu tidak terikat, sebagai anggota Firma atau si empunya andil pada M.A.B. Hanya uang andilnya tidak dapat ditariknya keluar dengan seketika itu juga. Biasanya, ditetapkan bahwa anggota yang keluar boleh menerima kembali uang andilnya sesudah ia berhenti setahun lamanya. Tanggung jawabnya terus sekian lama (Hatta, 1954: 190).

Ini maksudnya bukan untuk menahan anggota yang mau keluar itu, melainkan supaya kegoncangan hatinya itu jangan membahayakan akan kedudukan koperasi. Sebab, jika uang andilnya serentak dikeluarkan bersamasama dengan dia, kas koperasi bisa mendapat kesukaran (Hatta, 1954: 190).

Pendidikan moral yang ditekankan Hatta tidak terlepas dari pemahamannya tentang agama. Tujuan agama ialah memberi pegangan hidup kepada manusia sebagai individu dan sebagai anggota masyarakat untuk berbuat yang benar, yang baik, yang adil, yang jujur, dan yang suci supaya ada kesejahteraan dalam hidup manusia dan bangsa (Hatta, 1954: 45).

\section{Koperasi dan Demokrasi Ekonomi}

Demokrasi yang sebenarnya menghargai kritik, dan kritik dalam demokrasi harus dipikul oleh rasa tanggung jawab. Perasaan tanggung jawab itulah yang senantiasa dipupuk oleh perkumpulan koperasi. Dasar koperasi menghidupkan rasa tanggung jawab itu, sebab persekutuan koperasi, selain dari membela keperluan bersama, membangunkan dalam jiwa tiap-tiap anggotanya manusia merdeka dan insaf akan harga dirinya. Betapa juga lain sifatnya dari negeri ke negeri, ada lima dasar pokok yang tetap tidak berubah sejak timbulnya koperasi yang pertama di Rochdale tahun 1844, yaitu: (1) Perkumpulan koperasi dikemudikan oleh anggotanya sendiri. Seluruh anggota ikut serta membicarakan dalam rapat berkala segala hal yang mengenai keselamatan perusahaan. Oleh karena itu, tiap-tiap anggota merasa bertanggung jawab tentang jalannya perusahaan dan belajar cara bagaimana ia harus mengamatinya dangan tiada mengganggu atau menyukarkan kerja pimpinan. Memang tepat, apabila dasar ini disebut dasar demokrasi koperatif (Hatta, 1954: 220); (2) Tiap-tiap anggota mempunyai hak suara yang sama. Satu orang, satu suara. Tak peduli apakah iuran pokoknya atau simpanan pokoknya besar atau kecil. Tak ada anggota yang besar dan anggota yang kecil, semuanya sama rata, sama rasa. Dasar persamaan ini adalah corak yang kedua daripada demokrasi dalam gerakan koperasi (Hatta, 1954: 220); (3) Tiap-tiap orang dapat diterima menjadi anggota koperasi. Sebab itu, koperasi memperkuat kemauan harga-menghargai, sebab itu pula memberikan sumbangan yang sebaik-baiknya kepada perkembangan sifat sportif, yang sangat perlu untuk menumbuhkan demokrasi (Hatta, 1954: 220); (4) Keuntungan dibagi antara anggota menurut jasa mereka dalam memajukan perkumpulan. Misalnya, anggota yang banyak membeli barangbarang keperluannya pada koperasi, lebih banyak pula memperoleh bagian keuntungan daripada anggota yang sedikit membeli. Dasar ini disebut dasar demokrasi ekonomi dalam koperasi 
(Hatta, 1954: 220); dan (5) Satu bagian yang tertentu daripada keuntungan diuntukkan guna pendidikan. Apabila kita mau mengatur masyarakat kita di atas dasar koperasi, maka perlulah tiap-tiap cabang penghasilan, menurut jenis perusahaannya, didudukkan di atas dasar koperasi. Dengan organisasi koperasi, produksi itu hendaklah rakyat kita lambat-laun pandai dan dapat mengerjakan sendiri bahan-bahan yang dihasilkan (Hatta, 1987: 22).

Anggaran dasar koperasi itu mesti menerangkan maksudnya dan usahanya dengan sejelas-jelasnya. Hak dan kewajiban anggota mesti diatur betulbetul. Kalau anggota keluar dari perkumpulannya, sampai berapa lama terus tanggungannya. Dan kalau ada kerugian, bagaimana memikulnya kepada anggota-anggota koperasi itu. Kedudukan koperasi membawa pertanggungan bersama. Tetapi, oleh karena anggotanya tidak sama mampu, pembagian pertanggungan itu menurut keadilan harus ditentukan (Hatta, 1954: 133).

Sebaik-baik koperasi mempunyai badan penasihat dan badan pengawas. Ini menguatkan kedudukan koperasi di mata orang luar. Dalam anggaran dasar, disebutkan juga beberapa aturan tentang menjalankan pengawasan itu, supaya jangan timbul persengketaan kelak antara pengawas dan pengurus yang diawasi (Hatta, 1954: 133-134).

Bagi koperasi konsumsi, dimuat dalam anggaran dasarnya, larangan kepada anggotanya membeli barang ketempat lain, selama barang itu ada dijual oleh koperasi. Kecuali kalau pengurus mengizinkannya berhubung dengan keadaan yang luar biasa. Anggota pun tidak boleh menjual kembali kepada orang lain barang yang dibelinya pada koperasinya. Maksud koperasi konsumsi ialah membeli bersama untuk keperluan sendiri, bukan untuk menjualnya kembali. Dalam keadaan yang biasa, orang lain juga boleh membeli kepada koperasi itu.
Anggota yang membeli dan menjual lagi itu biasanya anggota yang curang. Maksudnya ialah mecari keuntungan baginya sendiri dari penjualannya kepada orang lain itu. Anggota yang semacam itu melanggar dasar perkumpulannya dan tak patut ditahan dalam koperasi. Larangan menjual kembali itu, mesti disebutkan didalam anggaran dasar (Hatta, 1954: 134).

Bagi koperasi kredit, mesti diadakan dalam anggaran dasarnya peraturan meminjamkan uang kepada anggotanya. Disebutkan juga aturan denda kepada anggota yang melanggar aturan meminjam itu. Selanjutnya, disebutkan pula asas-asas tentang mengurus dan menjalankan modal dan uang simpanan, yang tidak dipinjamkan kepada anggota. Ini perlu, karena anggota semuanya yang menanggung akibat tindakan pengurus atau pemimpin usaha (Hatta, 1954: 134135).

Suatu pasal yang penting juga bagi koperasi ialah cara memelihara kerukunan. Perselisihan antara anggota atau antara anggota dengan pengurus harus diperdamaikan dengan memberi kepuasan kepada kedua belah pihak. Oleh karena itu, anggaran dasar mestilah pula memuat peraturan tentang memperdamaikan perselisihan itu (Hatta, 1954: 135).

Siapa yang hendak membangun-kan koperasi, hendaklah tahu membedakan antara koperasi dan badan perusahaan yang lain, seperti Firma, P.T., dan M.A.B (Hatta, 1954: 189). Firma, P.T., dan M.A.B. didirikan untuk keperluan dagang. Dagang wujudnya mencari keuntungan (Hatta, 1954: 189).

Koperasi bukan persekutuan yang didirikan untuk mencari keuntungan, melainkan untuk membela keperluan bersama. Oleh karena itu, koperasi sifatnya "persekutuan cita-cita". Karena cita-cita yang sama, orang mendirikan koperasi. Kalau tidak ada cita-cita tinggi, yang menjadi pedoman berusaha, 
koperasi tidak bagus jalannya. Kepentingan diri sendiri jauh daripada koperasi. Koperasi yang sebenarnya berdasarkan kepada cita-cita tolongmenolong serta keinginan akan bantumembantu dalam kesukaran hidup (Hatta, 1954: 190).

\section{Konsep Rente (Bunga) menurut Bung Hatta}

Jika kaum ulama tidak memberi petunjuk yang jelas akan soal rente, kita coba bertanya kepada Alqur'an. Kata "rente", tidak disebut dalam Alqur'an, yang tersebut hanya pasal riba. Ada dua kali dikemukakan dengan nyata, dalam surat al-Baqarah (ayat 275 dan 276) dan surat ali-Imran (ayat 130) (Hatta, 1958: 212).

Riba sifatnya semata-mata konsumtif, Ia dimakan dari pada orang yang meminjamkan uang untuk melepaskan sesak hidupnya. Riba sematamata dipungut dari orang yang miskin, yang meminjamkan uang untuk keperluan hidupnya sebentar itu, dengan tiada berpikir panjang tentang melaratnya dikemudian hari. Tak pernah riba dapat dipungut dari orang yang meminjamkan uang buat membuka perusahaan, menimbang dulu "bunga uang" yang mesti dibayarnya (Hatta, 1958: 214-215).
Bunga uang yang dibayar bagi pinjaman uang untuk membuka perusahaan, disebut rente produktif. Rente itu adalah sebagian dari pada keuntungan yang diperoleh dengan bantuan uang orang lain itu. Bagi orang yang meminjamkan, perhitungannya didasarkan kepada kemungkinan mendapatkan laba dari pada uangnya itu (Hatta, 1958: 215).

Menurut Hatta (1958: 217), mengambil rente produktif, sifatnya berbagi keuntungan dengan orang yang menjalankan uang itu, dengan menetapkan bagian yang empunya kapital terlebih dahulu.

Selagi ada masyarakat individualisme, yang berdasarkan pertukaran barang dan jasa antara seorang dengan seorang, dan diantara badan-badan partikulir, selalu ada pembayaran. Jadinya, jasa kapital dibayar dengan rente, sebagaimana orang membayar jasa buruh dengan upah (Hatta, 1958: 217).

\section{PERSAMAAN, PERBEDAAN, DAN KONTRIBUSI KONSEP KOPERASI BUNG HATTA DENGAN KONSEP EKONOMI SYARIAH}

Adapun persamaan konsep koperasi Bung Hatta dengan konsep Ekonomi Syariah dapat dilihat pada tabel berikut:

\section{Tabel 1:}

Persamaan Konsep Koperasi Bung Hatta dengan Konsep Ekonomi Syariah

\begin{tabular}{|c|c|c|}
\hline Unsur-unsur & Konsep Koperasi Bung Hatta & Konsep Ekonomi Syariah \\
\hline Akad & $\begin{array}{l}\text { Koperasi merupakan usaha bersama } \\
\text { berdasar atas asas kekeluargaan. Artinya } \\
\text { setiap anggota koperasi bertanggung } \\
\text { jawab dalam perkembangan koperasi. } \\
\text { Berbeda halnya dengan PT, karena } \\
\text { anggota terbanyak tinggal pasif, } \\
\text { sedangkan pimpinan dan penyelengga- } \\
\text { raan perusahaan diserahkan kepada } \\
\text { beberapa orang saja. Di dalam koperasi, } \\
\text { anggota ikut serta dengan aktif untuk } \\
\text { memajukan koperasinya. } \\
\text { Dari penjelasan diatas, terlihat Hatta } \\
\text { memberikan sebuah konsep bahwa dalam } \\
\text { menjalankan sebuah usaha sebaiknya }\end{array}$ & $\begin{array}{l}\text { Pandangan Hatta ini jelas sangat sesuai } \\
\text { dengan konsep ekonomi syariah, yaitu } \\
\text { syirkah. Dimana sistem tersebut adalah } \\
\text { sistem kemitraan beberapa pihak dalam } \\
\text { sebuah usaha tertentu, serta keuntungan } \\
\text { dan kerugian ditanggung oleh kedua } \\
\text { belah pihak. Dengan demikian nilai usaha } \\
\text { bersama di dalam koperasi memiliki } \\
\text { persamaan dengan konsep ekonomi } \\
\text { syariah, yaitu syirkah. }\end{array}$ \\
\hline
\end{tabular}




\begin{tabular}{|c|c|c|}
\hline & $\begin{array}{l}\text { dengan bersama sesuai dengan yang } \\
\text { termuat dalam UUD } 1945 \text { pasal } 33 \text { ayat } 1 \\
\text { yang menyatakan bahwa perekonomian } \\
\text { disusun sebagai usaha bersama berdasar } \\
\text { atas asas kekeluargaan. }\end{array}$ & \\
\hline $\begin{array}{l}\text { Nilai-nilai } \\
\text { Dasar }\end{array}$ & $\begin{array}{l}\text { Bung Hatta juga menjelaskan bahwa } \\
\text { koperasi harus berdiri atas dua tiang, } \\
\text { yaitu solidaritet (setia bersekutu) dan } \\
\text { individualitet (kesadaran akan harga diri } \\
\text { sendiri). Rasa tanggung jawab terhadap } \\
\text { sesama maupun diri sendiri harus ada di } \\
\text { dalam anggota koperasi. Dengan adanya } \\
\text { rasa tanggung jawab terhadap sesama, } \\
\text { setiap anggota koperasi memiliki rasa } \\
\text { persaudaraan yang kuat sehingga tidak } \\
\text { terpengaruh terhadap konkurennya. Satu } \\
\text { sama lain saling membantu untuk } \\
\text { meringankan beban yang lain. }\end{array}$ & $\begin{array}{l}\text { Nilai solidaritet dan individualitet } \\
\text { memiliki kesamaan dengan konsep } \\
\text { ekonomi syariah, yaitu khilafah yang } \\
\text { secara umum berarti tanggung jawab } \\
\text { sebagai pengganti atau utusan Allah di } \\
\text { alam semesta. Manusia diciptakan Allah } \\
\text { untuk menjadi khalifah di muka bumi, } \\
\text { yaitu menjadi wakil Allah untuk } \\
\text { memakmurkan bumi dan alam semesta. } \\
\text { Rasa tanggung jawab sebagai seorang } \\
\text { muslim, menjadikan seseorang memiliki } \\
\text { rasa solidaritas dan individualitas. }\end{array}$ \\
\hline $\begin{array}{l}\text { Prinsip } \\
\text { tolong } \\
\text { menolong }\end{array}$ & $\begin{array}{l}\text { Dengan adanya rasa persaudaraan antar } \\
\text { anggota, menciptakan rasa tolong- } \\
\text { menolong. Anggota yang kekurangan di } \\
\text { tolong oleh anggota yang memiliki } \\
\text { kelebihan. Anggota yang kekurangan di } \\
\text { tolong oleh anggota yang memiliki } \\
\text { kelebihan. Setiap anggota menolong } \\
\text { anggota yang lain karena asas kekeluar- } \\
\text { gaan dari koperasi itu sendiri. Semangat } \\
\text { tolong menolong didorong oleh keinginan } \\
\text { memberikan jasa kepada yang lain. Baik } \\
\text { harta, tenaga, pikiran, dan waktu sebagai } \\
\text { bentuk rasa tolong menolong. }\end{array}$ & $\begin{array}{l}\text { Prinsip tolong menolong dalam } \\
\text { pandangan Hatta jelas sesuai dengan } \\
\text { prinsip ekonomi syariah. Hal itu sesuai } \\
\text { dengan firman Allah dalam Alqur'an surat } \\
\text { al-Maidah ayat } 2 \text { ( } \\
\text { "Dan tolong-menolonglah kamu dalam } \\
\text { (mengerjakan) kebajikan dan takwa" } \\
\text { Ta'awun merupakan konsep dasar yang } \\
\text { dijadikan asas untuk mengaplikasikan } \\
\text { teori Islam atas harta, dengan tanpa } \\
\text { adanya ta'awun, maka teori tersebut tidak } \\
\text { dapat diwujudkan. Harta kekayaan } \\
\text { bukanlah menjadi tujuan hidup, harta } \\
\text { berfungsi sebagai fungsi pokok kehidupan } \\
\text { dan mempunyai tugas-tugas sosial yang } \\
\text { cukup urgen, manusia sama di hadapan } \\
\text { Allah, dan yang membedakan adalah } \\
\text { kadar takwa yang akan menyampaikan } \\
\text { seorang hamba pada rahmat Allah. }\end{array}$ \\
\hline $\begin{array}{l}\text { Prinsip } \\
\text { Manfaat }\end{array}$ & $\begin{array}{l}\text { Koperasi bertujuan untuk mencapai } \\
\text { keperluan hidup bersama. Tidak hanya } \\
\text { sebatas mencari keuntungan semata. } \\
\text { Sehingga koperasi harus memperhatikan } \\
\text { kondisi baik di dalam tubuh koperasi itu } \\
\text { sendiri maupun di luar kopersi. Di dalam } \\
\text { koperasi, setiap anggota koperasi } \\
\text { memberikan manfaat kepada anggota } \\
\text { yang lainnya, tidak hanya mementingkan } \\
\text { diri sendiri. Begitu juga koperasi juga } \\
\text { harus memperhatikan kondisi lingkungan } \\
\text { sekitarnya. }\end{array}$ & 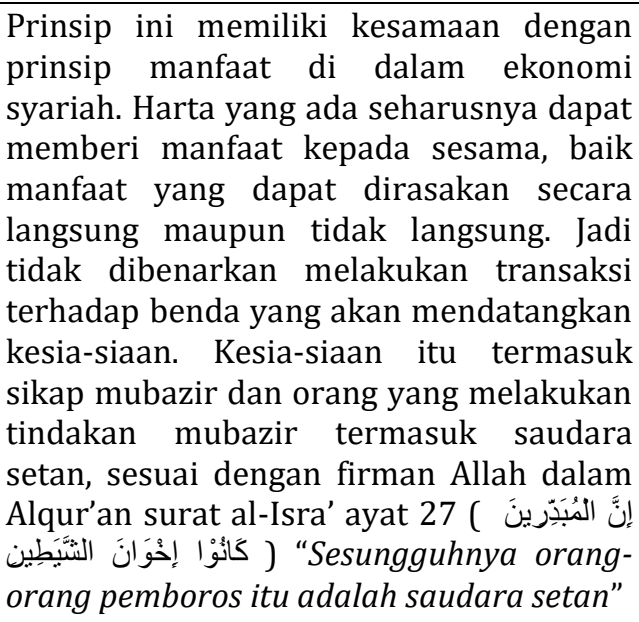 \\
\hline
\end{tabular}




\begin{tabular}{|c|c|c|}
\hline $\begin{array}{c}\text { Prinsip } \\
\text { Mashlahah }\end{array}$ & $\begin{array}{l}\text { Salah satu tugas koperasi adalah } \\
\text { memperbaiki harga. } \\
\text { dapat membantu masyarakat yang } \\
\text { berkekurangan } \\
\text { Sehingga mereka dapat membeli } \\
\text { kebutuhan sehari-hari. Koperasi menjadi } \\
\text { solusi dari oknum-oknum pedagang yang } \\
\text { suka menaikkan harga barang, karena } \\
\text { usaha bersama yang dilakukan } \\
\text { berdasarkan asas kekeluargaan. }\end{array}$ & $\begin{array}{l}\text { Jelas, tugas tersebut memiliki kesamaan } \\
\text { dengan prinsip mashlahah dalam } \\
\text { ekonomi syariah. Prinsip ini sejalan } \\
\text { dengan tujuan syariat (maqashid syariah) } \\
\text { yakni mendatangkan kemaslahatan dan } \\
\text { menghindari kemudaratan pada setiap } \\
\text { transaksi yang dilakukan. Perbaikan } \\
\text { harga yang dilakukan oleh koperasi } \\
\text { merupakan salah satu tujuan yang } \\
\text { mendatangkan kemaslahatan bagi } \\
\text { masyarakat yang memang membutuhkan. }\end{array}$ \\
\hline Fungsi & $\begin{array}{l}\text { Di dalam konsep koperasi Bung Hatta, } \\
\text { selain badan ekonomi, juga merupakan } \\
\text { badan sosial. Hal ini bertentangan dengan } \\
\text { paham koperasi barat, dimana koperasi } \\
\text { barat hanya sebatas badan ekonomi } \\
\text { semata. Koperasi sebagai bagian dari } \\
\text { masyarakat. Sebagian dari hasil usahanya } \\
\text { yang merupakan keuntungan } \\
\text { disumbangkan dengan kepada } \\
\text { masyarakat. Segala kegiatan yang } \\
\text { dilakukan harus memberikan manfaat } \\
\text { kepada sesama umat manusia. Koperasi } \\
\text { bukan hanya mementingkan kepentingan } \\
\text { anggotanya semata, akan tetapi lebih jauh } \\
\text { dari itu koperasi harus memberikan } \\
\text { kontribusi kepada masyarakat Indonesia } \\
\text { seperti yang terdapat pada tugas-tugas } \\
\text { koperasi. }\end{array}$ & $\begin{array}{l}\text { Konsep koperasi di dalam ekonomi } \\
\text { syariah pun, juga dapat berfungsi sebagai } \\
\text { badan sosial. Konsep koperasi syariah } \\
\text { mengharuskan memberikan pelayanan } \\
\text { sosial baik kepada anggota yang } \\
\text { membutuhkannya maupun kepada } \\
\text { masyarakat dhu'afa. Kepada anggota yang } \\
\text { membutuhkan pinjaman darurat } \\
\text { (emergency loan) dapat diberikan } \\
\text { pinjaman kebajikan dengan pengembalian } \\
\text { pokok (al-Qard). bagi anggota masyarakat } \\
\text { dhuafa dapat diberikan pinjaman } \\
\text { kebajikan dengan atau tampak } \\
\text { pengembalian pokok (qardhul hasan) } \\
\text { yang sumber dananya dari dana ZIS } \\
\text { (zakat, infak dan shadaqoh). }\end{array}$ \\
\hline Karakteristik & $\begin{array}{l}\text { Hatta menjelaskan bahwa dalam menjual } \\
\text { barang di koperasi harus benar ukuran } \\
\text { dan timbangannya. Hal ini menjadi } \\
\text { pendidikan bagi anggotanya untuk jujur } \\
\text { dalam bertransaski. Jika barang yang } \\
\text { dijual sudah tidak sesuai dengan harga } \\
\text { yang di tawarkan, maka keseimbangan } \\
\text { pasar akan terganggu. } \\
\text { Pendidikan moral yang diberikan Hatta ke } \\
\text { dalam koperasi tidak terlepas dari } \\
\text { pemahamannya tentang agama. Tujuan } \\
\text { agama ialah memberi pegangan hidup } \\
\text { kepada manusia sebagai individu dan } \\
\text { sebagai anggota masyarakat untuk } \\
\text { berbuat yang benar, yang baik, yang adil, } \\
\text { yang jujur, dan yang suci supaya ada } \\
\text { kesejahteraan dalam hidup manusia dan } \\
\text { bangsa. (Hatta, 1954: 45) } \\
\text { Hatta menjelaskan dengan adanya } \\
\text { koperasi, membentuk moral yang tinggi } \\
\text { dan menciptakan rasa tanggung jawab } \\
\text { untuk menjaga keselamatan } \\
\text { perusahaannya dan kepada sesama } \\
\text { manusia. }\end{array}$ & 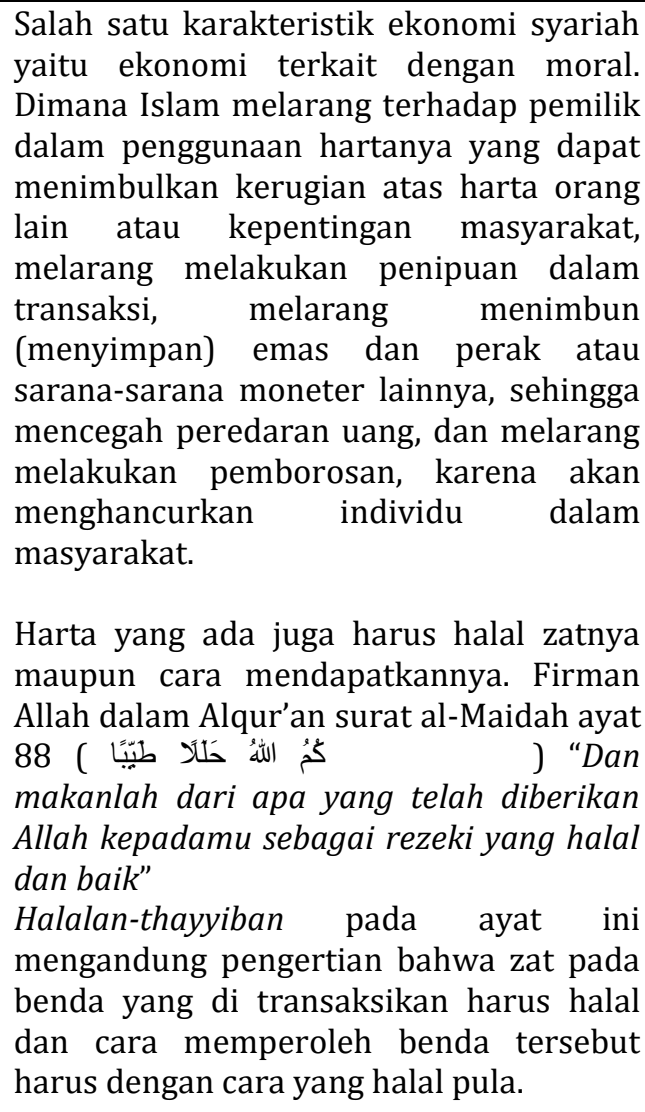 \\
\hline
\end{tabular}




\begin{tabular}{|c|c|c|}
\hline & $\begin{array}{l}\text { Menurut Hatta, koperasi seharusnya } \\
\text { memperbanyak produksi barang } \\
\text { makanan, kerajinan, dan pertukangan } \\
\text { yang dibutuhkan oleh rakyat. Koperasi } \\
\text { pertanian memperbanyak produksi hasil } \\
\text { taninya, koperasi kerajinan } \\
\text { memperbanyak hasil kerajinannya, dan } \\
\text { koperasi pertukangan memperbanyak } \\
\text { hasil yang sudah dikerjakannya. Dengan } \\
\text { memperbanyak hasil produksi, rakyat } \\
\text { tidak lagi ada kekurangan yang } \\
\text { mengakibatkan harga menjadi stabil. }\end{array}$ & $\begin{array}{l}\text { Tugas ini memiliki persamaan dengan } \\
\text { kaidah-kaidah berproduksi dalam Islam, } \\
\text { dimana produksi dimaksudkan untuk } \\
\text { memenuhi kebutuhan individu dan } \\
\text { masyarakat serta mencapai kemakmuran. } \\
\text { Dengan memperbanyak produksi, } \\
\text { masyarakat tidak lagi merasa } \\
\text { berkekurangan dalam memenuhi } \\
\text { kebutuhannya. }\end{array}$ \\
\hline Produksi & $\begin{array}{l}\text { Koperasi memperbaiki barang-barang } \\
\text { yang dihasilkan oleh rakyat. Hal ini bisa } \\
\text { dilakukan dengan memberikan pelatihan- } \\
\text { pelatihan kepada produsen, sehingga } \\
\text { mutu kualitas yang dihasilkan bernilai } \\
\text { tinggi. Hatta menjelaskan dengan adanya } \\
\text { koperasi, berbagai macam barang } \\
\text { penghasilan rakyat dapat diperbaiki } \\
\text { kualitasnya, bahkan kualitas produksi } \\
\text { nasional juga harus diperbaiki. Hatta } \\
\text { memberikan contoh getah yang } \\
\text { dihasilkan, dimana kualitasnya demikian } \\
\text { rendah sehingga perlu digiling kembali ke } \\
\text { Singapura. Dengan perbaikan kualitas } \\
\text { sedikit saja di Singapura harganya } \\
\text { menjadi tiga kali lipat. Disini Hatta } \\
\text { mengharapkan apabila di antara } \\
\text { pengusaha karet dapat didirikan koperasi, } \\
\text { maka dapat dibangun rumah-rumah } \\
\text { pengasapan karet kepunyaan bersama, } \\
\text { sehingga harganya meningkat sampai tiga } \\
\text { kali harga karet mentah tadi. }\end{array}$ & 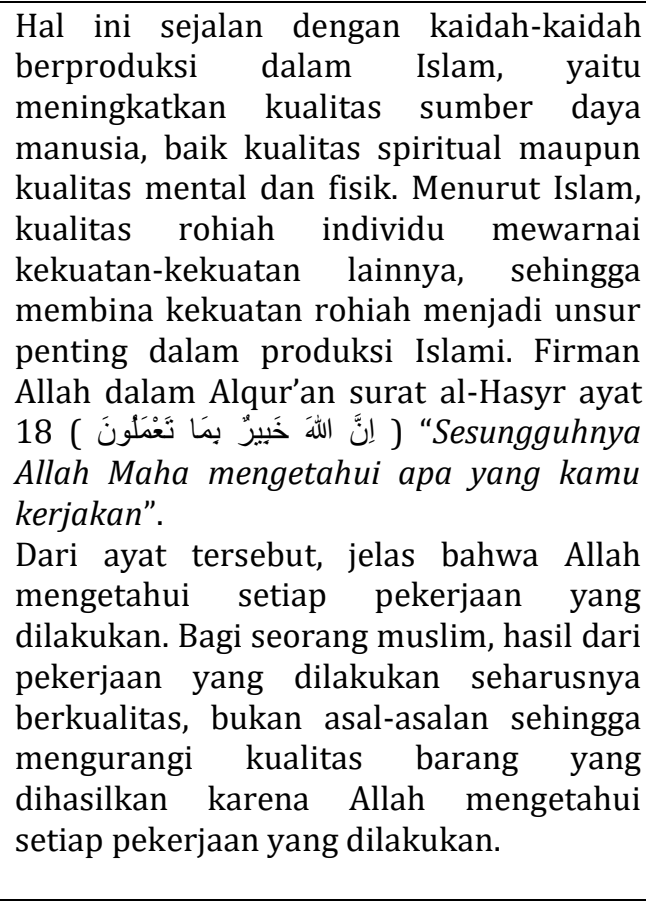 \\
\hline Distribusi & $\begin{array}{l}\text { Tujuan koperasi adalah melengkapi } \\
\text { keperluan bersama. Jadi koperasi } \\
\text { memperbaiki pendistribusian barang dari } \\
\text { satu tempat ke tempat lain untuk } \\
\text { melengkapi keperluan yang dibutuhkan. } \\
\text { Jika distribusi menjadi terhambat, akan } \\
\text { berdampak kepada kenaikan harga } \\
\text { barang yang akan memberatkan rakyat } \\
\text { kecil. Hal lain yang menjadi penghambat } \\
\text { distribusi adalah penimbunan barang dari } \\
\text { oknum yang suka mempermainkan harga. } \\
\text { Dengan adanya koperasi yang melengkapi } \\
\text { keperluan bersama akan lebih mudah } \\
\text { memperbaiki pendistribusian barang. }\end{array}$ & $\begin{array}{l}\text { Keselarasan ini juga berkaitan dengan } \\
\text { prinsip distribusi dalam Islam. Islam } \\
\text { mengarahkan mekanisme berbasis moral } \\
\text { spiritual dalam pemeliharaan keadilan } \\
\text { sosial pada setiap aktivitas ekonomi. } \\
\text { Latar belakangnya } \\
\text { ketidakseimbangan distribusi kekayaan } \\
\text { adalah hal yang mendasari hampir semua } \\
\text { konflik individu maupun sosial. } \\
\text { Penimbunan barang (Ihtikar) terhadap } \\
\text { kebutuhan barang-barang masyarakat } \\
\text { dilarang dalam Islam karena dapat } \\
\text { mengurangi tingkat produksi pasar dan } \\
\text { mengganggu kestabilan harga. }\end{array}$ \\
\hline
\end{tabular}

Sedangkan perbedaan konsep Ekonomi Syariah dapat dilihat dalam
koperasi Bung Hatta dengan konsep tabel berikut:


Tabel 2:

Perbedaan Konsep Koperasi Bung Hatta dengan Konsep Ekonomi Syariah

\begin{tabular}{|c|c|c|}
\hline Unsur-Unsur & Konsep Koperasi Bung Hatta & Konsep Ekonomi Syariah \\
\hline Landasan & $\begin{array}{l}\text { 1) Undang-Undang Dasar } 1945 \text { Pasal } 33 \\
\text { 2) Undang-Undang Republik Indonesia } \\
\text { nomor } 25 \text { tahun } 1992 \text { tentang } \\
\text { perkoperasian }\end{array}$ & $\begin{array}{l}\text { Landasan konsep ekonomi syariah sendiri } \\
\text { berasal dari Alqur'an dan hadits. Dimana } \\
\text { setiap teori yang dikemukan harus } \\
\text { memiliki dasar dari Alqur'an dan hadits. }\end{array}$ \\
\hline Bunga & $\begin{array}{l}\text { Hatta menjelaskan bahwa anggota yang } \\
\text { meminjam ditentukan jumlah } \\
\text { pinjamannya dan jangka waktu untuk } \\
\text { mengembalikan uang pinjaman itu } \\
\text { beserta rente yang sudah dimufakati. } \\
\text { Rente menurut Hatta merupakan } \\
\text { sebagian dari pada keuntungan yang } \\
\text { diperoleh dengan bantuan uang orang } \\
\text { lain. Bunga uang yang dibayar bagi } \\
\text { pinjaman uang untuk membuka } \\
\text { perusahaan, disebut rente produktif. } \\
\text { Menurut Hatta, mengambil rente } \\
\text { produktif, sifatnya berbagi keuntungan } \\
\text { dengan orang yang menjalankan uang itu, } \\
\text { dengan menetapkan bagian yang } \\
\text { empunya kapital terlebih dahulu. } \\
\text { Hatta menjelaskan bahwa riba sifatnya } \\
\text { konsumtif yang dipungut dari orang yang } \\
\text { miskin untuk keperluan hidupnya. } \\
\text { Sedangkan dalam hal bunga, Hatta } \\
\text { menyebutnya dengan rente produktif, } \\
\text { karena bunga yang diberikan sudah } \\
\text { diperhitungkan dari orang yang } \\
\text { meminjamkan uang buat membuka } \\
\text { perusahaan, menimbang dulu "bunga } \\
\text { uang"yang mesti dibayarnya. }\end{array}$ & $\begin{array}{l}\text { Islam menekankan pentingnya } \\
\text { memfungsikan uang pada bidangnya yang } \\
\text { normal, yaitu sebagai fasilitas transaksi } \\
\text { dan alat penilaian barang. Di antara faktor } \\
\text { yang menyelewengkan uang dari } \\
\text { bidangnya yang normal adalah bunga } \\
\text { (riba). } \\
\text { Memang paradoks dengan ekonomi } \\
\text { syariah, karena bunga bank bukan } \\
\text { merupakan karekteristik dari ekonomi } \\
\text { syariah. Dimana bunga bank sama dengan } \\
\text { riba, karena adanya penambahan dari } \\
\text { nilai peminjaman sebelumnya. } \\
\text { Namun hal ini juga menjadi beralasan } \\
\text { karena bank syariah belum berdiri pada } \\
\text { saat itu, sehingga Bung Hatta mencari } \\
\text { alternatif untuk kemaslahatan } \\
\text { masyarakat dalam meningkatkan taraf } \\
\text { hidup masyarakat setelah terlepas dari } \\
\text { penjajahan bangsa asing. }\end{array}$ \\
\hline $\begin{array}{c}\text { Badan } \\
\text { Pengawas }\end{array}$ & $\begin{array}{l}\text { Konsep koperasi Bung Hatta hanya } \\
\text { memiliki badan pengawas yang berfungsi } \\
\text { untuk mengawasi kebijakan koperasi }\end{array}$ & $\begin{array}{l}\text { Dalam konsep ekonomi syariah, koperasi } \\
\text { tidak hanya memiliki badan pengawas, } \\
\text { tetapi juga badan pengawas syariah yang } \\
\text { berfungsi untuk mengawasi kesesuaian } \\
\text { kegiatan operasional sesuai syariah. }\end{array}$ \\
\hline
\end{tabular}

\section{Kontribusi Konsep Koperasi Bung Hatta terhadap Perkoperasian di Indonesia dan Ekonomi Syariah}

Konsep koperasi Bung Hatta menjadi pilar perekonomian kerakyatan di Indonesia. Perekonomian kerakyatanmerupakan kancah kegiatan ekonomi orang kecil, yang karena merupakan kegiatan keluarga, tidak merupakan usaha formal berbadan hukum, tidak secara resmi diakui sebagai sektor ekonomi yang berperanan penting dalam perekonomian nasional. Sehingga keunggulannya adalah konsep koperasi Bung Hatta dapat diimplementasikan dari abad 19 hingga abad 20 pada saat sekarang ini dan tidak bertentangan dengan ekonomi syariah.

Konsep koperasi yang ditawarkan oleh Bung Hatta berkontribusi dalam perkembangan koperasi di Indonesia. Salah satu kontribusi Bung Hatta dalam mengembangkan koperasi adalah dengan memasukkan konsep koperasi di dalam UUD 1945, yaitu terdapat pada pasal 33 ayat 1 yang menyatakan bahwa 
perekonomian merupakan usaha bersama berdasar atas asas kekeluargaan, artinya mengutamakan kepentingan kolektif. Usaha bersama dilakukan dengan rasa persaudaraan karena berdasar atas asas kekeluargaan. Berbeda halnya dengan Perseroan Terbatas yang hanya diserahkan kepada beberapa orang saja. Sehingga keunggulannya adalah koperasi memiliki dasar hukum menjadi sebuah lembaga hingga saat sekarang ini dan terbentuknya koperasi syariah pun tidak terlepas dari UUD 1945 pasal 33 ayat 1 .

Rasa solidaritas dan individualitas memberikan kontribusi dalam meningkatkan taraf perekonomian masyarakat Indonesia. Hal ini bisa terwujud jika anggota koperasi benarbenar memiliki rasa solidaritas dan individualitas. Bentuk rasa solidaritas yaitu tolong menolong, gotong royong, dan tanggung jawab terhadap sesama, memberikan dampak yang besar bagi pemerataan ekonomi. Sedangkan rasa individualitas memberikan sebuah pemahaman kepada anggota untuk dapat meningkatkan kualitas sumber daya manusia. Dengan adanya peningkatan kualitas sumber daya, akan dapat meningkatkan tingkat produksi sehingga rakyat tidak lagi ada kekurangan yang mengakibatkan harga menjadi stabil. Peningkatan kualitas juga dapat dilakukan dengan memperbaiki barangbarang yang dihasilkan oleh rakyat. Hal ini bisa dilakukan dengan memberikan pelatihan-pelatihan kepada produsen, sehingga mutu kualitas yang dihasilkan bernilai tinggi. Diharapkan dengan adanya rasa solidaritas dan individualitas, koperasi memberikan kontribusi dalam mengatasi permasalahan perekonomian bangsa Indonesia. Keunggulan dari sifat solidaritas dan individualitas adalah setiap anggota memiliki rasa tanggung jawab, baik terhadap diri sendiri maupun terhadap sesama sehingga koperasi memiliki pertumbuhan ekonomi yang stabil dan sifat ini sangat sesuai dengan konsep ekonom syariah.

Koperasi memberikan kontribusi dalam pelayanan sosial. Tidak hanya berorientasi kepada fungsi ekonomi, melainkan juga fungsi sosial yang memang dibutuhkan oleh rakyat Indonesia pada saat sekarang ini. Hal inilah yang membedakan koperasi barat dengan konsep koperasi Bung Hatta. Keunggulan dari konsep koperasi Bung Hatta, selain badan ekonomi, juga merupakan badan sosial. Hal ini bertentangan dengan paham koperasi barat, dimana koperasi barat hanya sebatas badan ekonomi semata. Koperasi sebagai bagian dari masyarakat. Sebagian dari hasil usahanya yang merupakan keuntungan disumbangkan dengan kepada masyarakat. Segala kegiatan yang dilakukan harus memberikan manfaat kepada sesama umat manusia.

Koperasi memberikan kontribusi dalam hal pendidikan. Dengan adanya pendidikan koperasi ditanamkan kepada seluruh orang yang terlibat di koperasi agar punya sifat gotong royong, toleransi, saling bekerja sama, mandiri, gemar menyimpan, sabar, dan sikap-sikap baik lainnya. Justru tujuan utama koperasi menurut Bung Hatta adalah agar koperasi menjadi sarana pendidikan moril bagi masyarakat dan anggota koperasi pada khususnya. Dari moril dan sikap yang baik itu maka sudah setengah jalan menuju masyarakat yang sejahtera sebagaimana dicita-citakan oleh koperasi. Bahkan Bung Hatta memberikan usulan untuk didirikan sekolah menengah koperasi yang memberikan didikan sistematis untuk membangun jiwa koperasi. Pendidikan moral yang ditekankan Hatta tidak terlepas dari pemahaman-nya tentang agama. Tujuan agama ialah memberi pegangan hidup kepada manusia sebagai individu dan sebagai anggota masyarakat untuk berbuat yang benar, yang baik, yang adil, yang jujur, dan yang suci supaya ada 
kesejahteraan dalam hidup manusia dan bangsa.

Lebih jauh sebagai sebuah badan usaha, koperasi berkontribusi bagi pertumbuhan perekonomian nasional. Hal ini dapat dilihat dari berbagai tugas dari koperasi yang tidak hanya menyentuh sektro mikro akan tetapi sudah mencakup sektor makro. Sehingga, konsep koperasi Bung Hatta memiliki keunggulan, yaitu Dengan memperbanyak hasil produksi, rakyat tidak lagi ada kekurangan yang mengakibatkan harga menjadi stabil, dengan memperbaiki kualitas dapat meningkatkan harga barang, dan dengan memperbaiki distribusi harga barang kebutuhan menjadi stabil.

\section{SIMPULAN}

Dari hasil penelitian oleh penulis, dapat ditarik kesimpulan bahwa konsep koperasi Bung Hatta, meliputi: (a) Koperasi merupakan usaha bersama berdasar atas asas kekeluargaan; (b) Konsep koperasi Bung Hatta didasarkan kepada semangat kolektivisme masyarakat yang sudah ada di dalam kebiasaan masyarakat Indonesia; (c) Koperasi bukan hanya merupakan badan ekonomi, akan tetapi juga merupakan badan sosial yang bertanggung jawab terhadap masyarakat disekitarnya; (d) Koperasi juga sebagai wadah untuk mendidik para anggotanya untuk memiliki sifat solidaritet (setia berekutu) dan individualitet (kesadaran akan harga diri sendiri); (e) Koperasi memberikan pendidikan moril agar anggotanya memiliki cita-cita yang tinggi; dan (f) Koperasi bertugas memperbanyak produksi, memperbaiki kualitas, dan memperbaiki distribusi

Sedangkan pandangan konsep koperasi Bung Hatta dalam perspektif ekonomi syariah, yaitu: (a) Adanya kesamaan antara konsep koperasi Bung Hatta dengan konsep ekonomi syariah, yaitu tentang konsep syirkah (usaha bersama), menciptakan persaudaraan dan keadilan sesama, prinsip manfaat, prinsip mashlahah, nilai khilafah, distribusi, dan ta'awun; (b) Terdapat perbedaan antara konsep koperasi Bung Hatta dengan konsep ekonomi syariah, yaitu landasan konsep koperasi Bung Hatta yaitu tersapat pada Undang-Undang Dasar 1945 pasal 33 dan Undang-Undang Republik Indonesia nomor 25 tahun 1992. Sedangkan konsep ekonomi syariah yang berlandaskan Alqur'an dan hadits dan mencantumkan dalil di setiap teorinya; (c) Konsep koperasi Bung Hatta memiliki keterkaitan dengan konsep ekonomi syariah. Hal ini dapat diketahui dari beberapa persamaan konsep koperasi Bung Hatta yang ternyata terdapat nilai-nilai ekonomi syariah; dan (d) Konsep koperasi Bung Hatta memberikan kontribusi terhadap perkoperasian di Indonesia dan ekonomi syariah.

\section{DAFTAR KEPUSTAKAAN}

Amalia, Euis. 2010. Sejarah Pemikiran Ekonomi Islam dari Masa Klasik hingga Kontemporer. Depok: Gramata Publishing.

Ammar, Abu dan Al-Adnani, Abu Fatiah. 2016. Mizanul Muslim, Barometer Menuju Muslim Kaffah. Solo: Cordova Mediamata.

Arifin, E. Zaenal dan Tasai, S. Amran. 2009. Cermat Berbahasa Indonesia untuk Perguruan Tinggi. Jakarta: Akademika Pressindo.

Baalbaki dan Baalbaki, Rohi. 2006. Kamus Al-Maurid, Arab-Inggris-Indonesia. Surabaya: Halim Jaya.

Bakhri, B. S. 2011. Sistem Ekonomi Islam dalam Perbandingan. Al-Hikmah: Jurnal Agama dan Ilmu Pengetahuan, 8(1), 42-49.

Basya, Ahmad Fahmi. 2015. Analisis Pemikiran Bung Hatta tentang Persoalan Ekonomi Sosialis Indonesia dalam Perspektif 
Ekonomi Islam. Skripsi. Surabaya: Universitas Islam Negeri Sunan Ampel.

Buchori, Nur S., 2009. Koperasi Syariah. Sidoarjo: Masmedia Buana Pustaka.

Case, Karl E. dan Far, Ray C. 2007. Prinsipprinsip Ekonomi Mikro. Klaten: Macanan Jaya Cemerlang.

Departemen Agama RI. 2010. Alqur'an Terjemahan Perkata. Bandung: Mizan Pustaka.

Departemen Pendidikan Nasional. 2008. Kamus Besar Bahasa Indonesia. Jakarta: Pusat Bahasa.

Echols, John M. dan Shadily, Hassan. 2010. An English Indonesian Dictionary. Jakarta: Gramedia Pustaka Utama.

Effendi, Rustam. 2002. Produksi dalam Perspektif Islam. Tesis. Yogyakarta: Universitas Islam Indonesia. . 2003. Produksi dalam Islam. Yogyakarta: Magistra Insania Press.

Fauzia, Ika Yunia dan Riyadi, Abdul Kadir. 2014. Prinsip Dasar Ekonomi Islam. Jakarta: Kencana Prenadamedia Group.

Hak, Nurul. 2011. Ekonomi Islam Hukum Bisnis Syari'ah. Yogyakarta: Teras.

Hatta, Mohammad. 1958. Beberapa Fasal Ekonomi, Djalan Keekonomi dan Bank. Jakarta: Balai Pustaka.

1954. Beberapa Fasal Ekonomi, Djalan Keekonomi dan Kooperasi. Jakarta: Perpustakaan Perguruan Kementrian.

1954. Kumpulan Karangan.

Jakarta: Balai Buku Indonesia. 1968. Masalah Bantuan Perkembangan Ekonomi Bagi Indonesia. Jakarta: Djambatan.

1967. Teori Politik dan Orde Ekonomi. Jakarta: Tintamas. . 1987. Membangun Koperasi dan Koperasi Membangun. Jakarta: Inti Idayu Press.

. 1954. Pengantar ke Djalan Ilmu dan Pengetahuan. Jakarta: Pembangunan.
Hendar. 2010. Manajemen Perusahaan Koperasi. Jakarta: Erlangga.

Hendrojogi. 2007. Koperasi: Asas-asas, Teori dan Praktik. Jakarta: RajaGrafindo Persada.

Hoeve, Ichtiar Baru van. 2008. Himpunan Peraturan Perundang-Undangan Republik Indonesia. Jakarta.

Huda, Nurul. et.al., 2008. Ekonomi Makro Islam: Pendekatan Teoritis. Jakarta: Prenada Media Group.

Ibrahim. 2015. Metodologi Penelitian Kualitatif, Panduan Penelitian beserta Contoh Proposal Kualitatif. Pontianak: Perpustakaan Nasional.

Junaidi, Hindi. 2011. Studi terhadap Konsep Ekonomi Kerakyatan Mohammad Hatta Menurut Perspektif Ekonomi Islam. Skripsi. Universitas Islam Negeri Sultan Syarif Kasim, Riau.

Karim, Adiwarman Azwar. 2010. Ekonomi Mikro Islam. Jakarta: Rajawali Pers. 2010. Sejarah Pemikiran Ekonomi Islam. Jakarta: Raja Grafindo Persada.

Mardani. 2013. Fiqh Ekonomi Syariah: Fiqh Muamalah. Jakarta: Kencana Prenadamedia Group.

Misanam, Munrokhim, et.al., 2011. Ekonomi Islam. Jakarta: Raja Grafindo Persada.

Moeimam dan Steinhauer, Hein. 2008. Kamus Belanda-Indonesia. Jakarta: Gramedia Pustaka Utama.

Mubyarto, et.al. 2014. Ekonomi Kerakyatan. Jakarta: Lembaga Suluh Nusantara.

Muljono, Djoko. 2012. Buku Pintar Strategi Bisnis Koperasi Simpan Pinjam. Yogyakarta: Andi.

Narbuko, Cholid dan Achmadi, Abu. 2012. Metodologi Penelitian. Jakarta: Bumi Aksara.

Nasution, Mustafa Edwin. 2010. Pengenalan Eksklusif Ekonomi Islam. Jakarta: Prenada Media Group. 
Noer, Deliar. 2012. Mohammad Hatta, Hati Nurani Bangsa. Jakarta: Kompas Media Nusantara.

Praptanto, Eko. 2010. Sejarah Indonesia, Zaman Kebangkitan Nasional. Jakarta: Bina Sumber Daya MIPA.

Prastowo, Andi. 2016. Metode Penelitian Kualitatif. Jakarta: Ar-Ruzz Media.

Rosyidi, Suherman. 2014. Pengantar Teori Ekonomi. Depok: Rajagrafindo Persada.

Rozalinda. 2016. Fikih Ekonomi Syariah. Jakarta: Rajawali Pers.

Sanusi, Anwar. 2014. Metodologi Penelitian Bisnis. Jakarta: Salemba Empat.

Setiyarini, Herlina. Pemikiran Mohammad Hatta Tentang Ekonomi Koperasi Tahun 1925-1953. Avatara, Jurnal Pendidikan Sejarah Vol.2, No.3, 211223, 2014.

Setyawan, Dharma. 2014. Haji Agus Salim, The Grand Old Man. Bandar Lampung: Indepth Publishing.
Soesilo, H.M. Iskandar. 2008. Dinamika Gerakan Koperasi Indonesia, Corak Perjuangan Ekonomi Rakyat dalam Menggapai Sejahtera Bersama. Jakarta: Wahana Semesta Intermedia.

Subandi. 2010. Ekonomi Koperasi (Teori dan Praktik). Bandung: Alfabeta.

Swasono, Meutia Farida. 1981. Bung Hatta, Pribadinya dalam Kenangan. Jakarta: Sinar Harapan.

Teeuw, A., 2009. Kamus Indonesia Belanda. Jakarta: Gramedia.

Widiyanti, Ninik dan Sunindhia, Y.W. 2008. Koperasi dan Perekonomian Indonesia. Jakarta: Rineka Cipta.

Zulkifli, Z., \& Murdiana, D. 2018. Hubungan Kompetensi Lulusan Sarjana Ekonomi Syariah dengan Dunia Kerja. Al-Hikmah: Jurnal Agama dan Ilmu Pengetahuan, 12(1), 24-112. 